\title{
Does Procyclical Fiscal Policy Reinforce Incentives to Dollarize Sovereign Debt?
}

\author{
Anastasia Guscina, Anna Ilyina and \\ Herman Kamil
}


(C) 2010 International Monetary Fund

$\mathrm{WP} / 10 / 168$

\title{
IMF Working Paper
}

European Department, Monetary and Capital Markets Department, and Western Hemisphere Department

\section{Does Procyclical Fiscal Policy Reinforce Incentives to Dollarize Sovereign Debt?}

\author{
Prepared by Anastasia Guscina, Anna Ilyina and Herman Kamil ${ }^{1}$ \\ Authorized for distribution by Erik De Vrijer
}

July, 2010

\begin{abstract}

\section{This Working Paper should not be reported as representing the views of the IMF.} The views expressed in this Working Paper are those of the author(s) and do not necessarily represent those of the IMF or IMF policy. Working Papers describe research in progress by the author(s) and are published to elicit comments and to further debate.

This paper explores the link between the cyclical patterns of macroeconomic and policy variables and the currency composition of domestic sovereign debt in emerging market countries. The empirical analysis is anchored in an equilibrium model, in which the dollarization of sovereign debt arises as a result of the optimal portfolio choices by riskaverse investors, and of a sovereign debt manager who takes fiscal policy as given. The model predicts that in countries where the exchange rate is countercyclical (i.e., the exchange rate depreciates during recessions), a more procyclical fiscal policy (i.e., expansionary in good times and contractionary in bad times) would lead, on average, to a more dollarized domestic sovereign debt. The empirical analysis using the Jeanne-Guscina EM Debt database (2006) on the currency structure of the central government debt in 22 emerging market countries over 1980-2005, supports these predictions.
\end{abstract}

JEL Classification Numbers: C24, C23, F34, F39, G15, H30, H63

Keywords: Dollarization, sovereign debt, fiscal policy, sovereign debt management Author's E-Mail Address: aguscina@,imf.org; ailyina@imf.org; hkamil@,imf.org

\footnotetext{
${ }^{1}$ The authors would like to thank Erik De Vrijer, Olivier Jeanne, Roberto Samaniego, Julien Reynaud, Gil Mehrez, Ashoka Mody, Natalia Trubnikov, and participants at the IMF European Department seminar. All remaining errors are ours.
} 


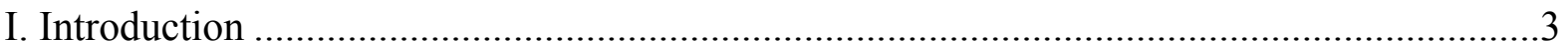

II. Cyclical Patterns in Macroeconomic an d Policy Variables in EMs..................................5

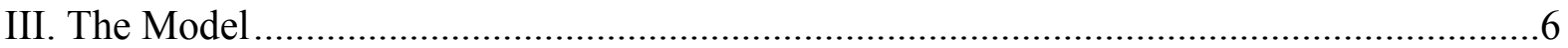

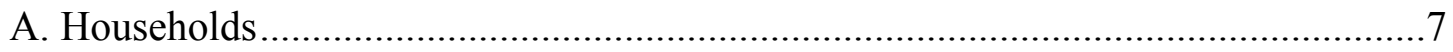

B. Fiscal Policy and Sovereign Debt Management ............................................. 11

C. Equilibrium in the Domestic Bond Market ...................................................... 14

IV. Testing the Empirical Implications of the Model .......................................................15

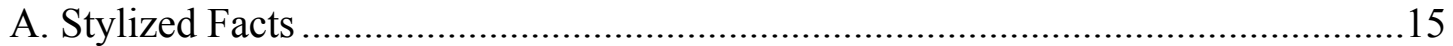

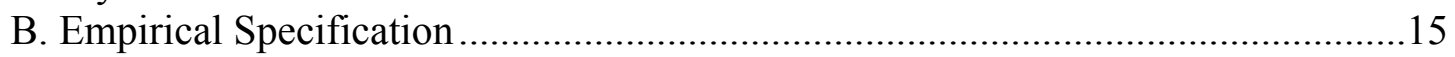

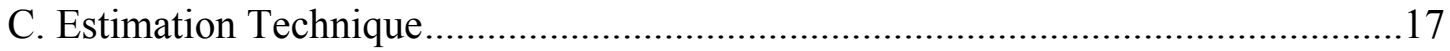

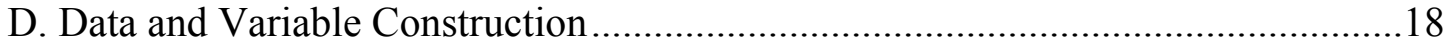

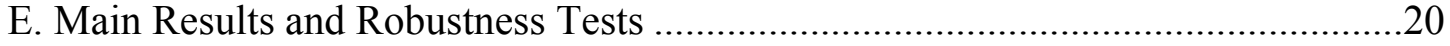

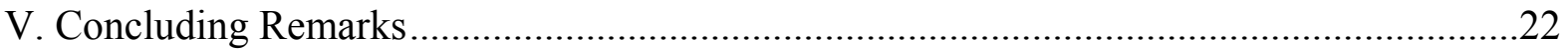

Appendix I. Derivations of Theoretical Expressions .......................................................36

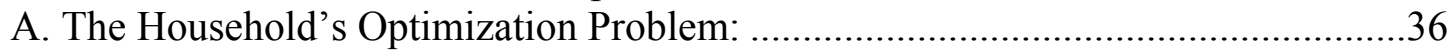

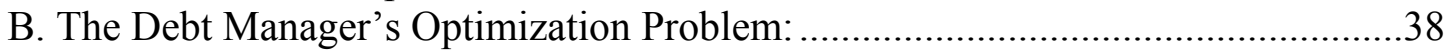

C. Domestic Bond Market Clearing Condition: .......................................................39

Appendix II. Derivations of Corrected Interaction Effect ...............................................40

A. Marginal Effects of Variables in Levels and Interaction Term on $E(y \mid \mathbf{x}) \ldots \ldots \ldots . . .40$

Tables

1. Countercyclicality of the Exchange Rate: Summary Statistics.......................................32

2. Procyclicality of Fiscal Policy: Summary Statistics ....................................................33

3. Results of Censored Tobit Estimation-Pooled Data: 1980-2005 ..................................34

4. Robustness Checks for Censored Tobit Estimation: 1980-2005 ......................................35

Figures

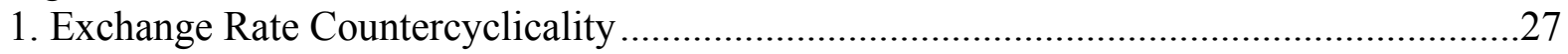

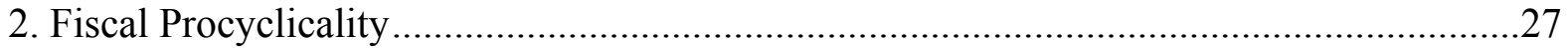

3. Dollarization of Sovereign Debt and Dollarization of Bank Loans \& Deposits ................28

4a. Latin America-Domestic Sovereign Debt Structure-Selected Countries .......................29

4b. EM Europe-Domestic Sovereign Debt Structures-Selected Countries ............................30

5. Effect of Countercyclicality of the Exchange Rate on Dollarization of Sovereign Debt, for Different Levels of Fiscal Procyclicality 


\section{INTRODUCTION}

A string of capital account crises in the 1990s and early 2000s attracted a lot of attention to the issue of excessive reliance of emerging market (EM) borrowers on foreign currency debt. Research in this area produced overwhelming evidence that currency mismatches (a situation in which foreign currency debt is not backed up by foreign currency assets) increase the likelihood and severity of financial distress. ${ }^{2}$ The impact of the recent global financial crisis on some EMs has only confirmed the validity of these conclusions.

Why do EM sovereigns and their lenders settle on debt that seems to be crisis-prone? While academic research has provided many insights into the currency composition of external sovereign debt (i.e., debt issued in foreign jurisdictions), relatively few studies have investigated this issue in the context of domestic debt (i.e., debt issued in national jurisdictions). ${ }^{3}$ This is despite the important role played by sovereign domestic debt in several EM crises (Mexico, 1994; Russia, 1998 and Brazil,1998) as well as the fact that in many countries domestic debt accounts for a larger part of public debt than external debt (Jeanne and Guscina, 2006).

The focus on domestic sovereign debt has several advantages. First, it allows disentangling the location (jurisdiction) decisions from the currency of denomination decisions of EM sovereigns. ${ }^{4}$ Second, the focus on domestic debt shifts attention from the foreign creditors' reluctance to lend in EM currencies to the EM sovereigns' incentives to borrow (and the domestic investors' incentives to save) in foreign currencies. Third, because cross-country heterogeneity in the currency composition of domestic sovereign debt is significantly higher than that of the internationally issued EM debt, the focus on domestic debt should allow a more accurate empirical identification of the determinants of its currency composition. Given the advantages mentioned above, the apparent scant attention devoted to the currency

\footnotetext{
${ }^{2}$ An extensive literature on emerging market crises explored the links between foreign currency debt, exchange rate instability and the likelihood of financial crises. See Bordo and Meissner (2005) for recent empirical findings and an overview of the related literature.

${ }^{3}$ The "original sin" literature has focused mainly on external sovereign debt, attributing its predominantly foreign currency denomination to the lenders' preferences, which have been influenced by the history of crises and macroeconomic instability in EMs (Hausmann and Panizza, 2003). The pervasive foreign currency contracting in international markets can also be seen as a response to the difficulties in enforcing contracts on sovereign borrowers: a debt structure skewed toward foreign-currency debt can serve as a mechanism for reducing moral hazard on the part of policy makers (Chamon, 2003; Jeanne, 2000, 2004; Tirole, 2002). In this context, the issuance of dollar debt - which cannot be inflated away - may also be a deliberate decision by the EM policy makers to enhance credibility of monetary stabilization efforts (Calvo, 1980; Calvo and Guidotti, 1990).

${ }^{4}$ The difficulty in separating the location of issuance decisions (onshore versus offshore) from the currency of denomination decisions has been mainly due to the lack of a comprehensive cross-country data on the currency composition of domestic sovereign debt (see, e.g., Claessens et al, 2007).
} 
composition of domestic sovereign debt is likely to be due to the fact that the cross-country data on domestic public debt "remains curiously exotic" (as noted in Reinhart and Rogoff, 2008).

This paper contributes to the literature in two ways. First, we develop a model where the optimal currency composition of domestic sovereign debt is an outcome of portfolio choices of households and the sovereign debt manager who takes the cyclical patterns of macroeconomic and policy variables as given. Second, focusing on the currency structure of domestic sovereign debt, we test the predictions of the model using a novel dataset on the structure of central government debt in 22 EM countries over 1980-2005 constructed by Jeanne and Guscina (2006).

We show that when households and sovereign debt manager are risk averse and there is no risk of default, the equilibrium currency composition of sovereign debt will be tilted towards the instruments that represent a better hedge against the exchange rate, inflation and/or output shocks. ${ }^{5}$ The main predictions of the model are as follows:

- $\quad$ Countries where the real exchange rate is less volatile than the domestic inflation rate would have, on average, a more dollarized domestic sovereign debt. This is because both households and debt manager are risk averse and hence, dislike volatility in the yields on sovereign bonds. The households would prefer to hold more foreign currency bonds if the real exchange rate (which determines the return volatility of foreign currency bonds measured in units of local consumption basket) is less volatile than the domestic inflation rate (which determines the volatility of real return on local currency bonds). Same is true for the debt manager's incentives to issue such bonds, as she also dislikes the volatility of the real sovereign bond yields. ${ }^{6}$

- In countries where the exchange rate is countercyclical (i.e., the exchange rate depreciates during recessions), a more procyclical fiscal policy (i.e., expansionary in good times and contractionary in bad times) would lead, on average, to a more dollarized domestic sovereign debt. This is because both households and the sovereign debt manager care about the capacity of financial assets to provide a hedge against output shocks that affect the households' non-financial income and the sovereign's tax revenues (which, in turn, determine its debt servicing capacity). Foreign currency bonds represent a better hedge against output shocks when

\footnotetext{
${ }^{5}$ While the incentives of households (debt manager) to hold (issue) foreign currency bonds are influenced by the real interest rate differential between local and foreign currency bonds, what matter in equilibrium are the hedging prosperities of these instruments against various types of shocks.

${ }^{6}$ This result is similar to the one obtained in Ize and Levy-Yeyati (2003), who characterize financial dollarization as an outcome of portfolio decisions of depositors and banks. Their main result is that financial dollarization is persistent when the volatility of the inflation rate is high relative to the volatility of the real exchange rate.
} 
exchange rate is countercyclical. ${ }^{7}$ A more procyclical fiscal policy increases the procyclicality of households' non-financial incomes and hence, their incentives to hold foreign currency bonds. In addition, we also show that when fiscal policy is highly procyclical, it creates perverse incentives for the debt manager to prefer to issue more foreign currency debt, reinforcing the foreign currency preferences of households.

While the link from more dollarized sovereign debt to more procyclical fiscal policy is well understood, few studies have looked at the two-way link between fiscal pro-cyclicality and the currency composition of sovereign debt. ${ }^{8}$ Indeed, in countries where negative output shocks are associated with exchange rate depreciations, a higher share of sovereign dollar debt would tend to reinforce procyclical fiscal policy because the real debt burden of a more dollarized sovereign would rise by more in bad times. This paper shows that the converse may be true as well, i.e., when the exchange rate is countercyclical, procyclical fiscal policy may lead to a more dollarized sovereign debt.

The empirical predictions of the model are tested using a novel dataset on the currency composition of domestic sovereign debt in 22 EM countries over 1980-2005. The results of the empirical analysis support the model predictions and appear to be robust under a range of specifications and estimation methods. In particular, the empirical analysis confirms that countries with relatively high inflation uncertainty tend to have higher levels of dollarization of sovereign debt, and that in countries where the exchange rate is countercyclical, a more procyclical fiscal policy tends to be associated with more dollarized domestic sovereign debt.

The structure of the paper is as follows: Section II presents the key stylized facts on cyclical patterns in macroeconomic and policy variables in EMs. Section III introduces the model, Section IV presents the results of the empirical analysis, and Section V concludes the paper.

\section{Cyclical Patterns in Macroeconomic an d Policy Variables in EMs}

The relationships between macroeconomic and policy variables assumed in this paper reflect the salient features of EM and developing economies, namely:

- Nominal exchange rate changes and domestic price changes have positive covariance.

\footnotetext{
${ }^{7}$ This result is consistent with Lane and Shambaugh (2010), who find that an increase in the propensity for a currency to depreciate during bad times is associated with a longer position in foreign currencies, providing a hedge against domestic output fluctuations. Ize (2005) shows that in a special case of the financial dollarization model (when all agents are risk averse and neither corporates nor banks default), a negative correlation between investors' non financial incomes and the exchange rate (devaluations coincide with output contractions) would further promote the use of foreign currency as "safe haven".

${ }^{8}$ One exception is the recent paper by Adler (2008), where procyclicality of fiscal policy arises as a by-product of the "original sin" and both fiscal procyclicality and "original sin" are explained by the presence of weak monetary institutions.
} 
- Nominal exchange rate depreciations (appreciations) tend to be associated with downturns (upturns) in economic activity - this phenomenon will henceforth be referred to as the exchange rate countercyclicality ${ }^{9}$

- $\quad$ Fiscal policies tend to be expansionary (contractionary) during the upturns (downturns) in economic activity - which will be referred to as fiscal procyclicality ${ }^{10}$.

There is an extensive literature documenting the phenomenon of fiscal procyclicality in EM and developing countries, as well as explaining its causes. ${ }^{11}$ Riascos and Vegh (2003), for example, argue that the incompleteness of financial markets in EMs could explain the procyclicality of fiscal policy as an outcome of a Ramsey problem. Lane and Tornell (1999) offer political economy explanation, namely the "voracity effect,"-in times of plenty fiscal resources are wasted and not saved for bad times. Alesina, et al (2006) explain this as an outcome of the political agency problem, where rational voters demand more public goods or fewer taxes in good times in order to reduce political rents, thereby, inducing a procyclical bias. More recently, Ilzetzki and Vegh (2008) present overwhelming evidence of fiscal policy procyclicality in developing countries by running a battery of tests on a dataset of 49 countries over the period 1960-2006.

Moreover, the theoretical literature (e.g, Talvi and Vegh (2005)) has shown that when fluctuations in the tax base are large (which is typical for developing countries and EMs), the government may find it optimal to run a procyclical fiscal policy. ${ }^{12}$ This implies, among other things, that other economic agents would be taking the cyclical features of fiscal policy as exogenous when making portfolio decisions.

\section{THE MODEL}

We consider a two-period model of an economy that is subject to exogenous output shocks, as well as price and exchange rate uncertainty. We assume that households are the only

\footnotetext{
${ }^{9}$ See Figure 1 (All Figures and Tables are at the end of the paper). The summary statistics on the degree of the exchange rate countercyclicality for individual countries in the sample are in Table 1.

${ }^{10}$ See Figure 2. The summary statistics on the degree of fiscal policy procyclicality for individual countries in the sample are presented in Table 2.

${ }^{11}$ Since many EM and developing countries depend on foreign credit, periods of sudden stops tend to be associated with economic downturns, restrictive macroeconomic policies (including fiscal tightening) and exchange rate depreciations. Thus, in the EM countries, the capital flow cycle and the macroeconomic policy cycle tend to reinforce each other in a phenomenon labeled by Kaminsky et al. (2004) "when it rains it pours."

${ }^{12}$ In a standard tax smoothing model, the path of government spending is taken as exogenous and the main objective of the sovereign is to smooth taxes over time or across states of nature in order to minimize distortions. In such models, tax rates as well as government spending are assumed to be uncorrelated with any shocks to the tax base. The latter does not hold in the case of developing countries.
} 
potential buyers of financial assets and that government bonds are the only available financial assets.

There is no investment. The households' wealth is derived from two sources: output and financial asset holdings. The portfolio allocation decision of a household is thus driven by the financial diversification motive and by the need to hedge non-financial income against output shocks.

There is no default in the model. The government can issue two types of bonds: domestic currency denominated or foreign currency denominated bonds. The nominal interest rate in foreign currency, $r^{*}$, is exogenous, while the nominal interest rate in domestic currency, $i^{*}$, is determined by the domestic bond market clearing condition. In this model, the government's behavior is defined by fiscal rules that determine the amount of taxes and transfers as a function of output.

Taking these fiscal rules as given, the sovereign debt manager chooses the currency composition of sovereign debt in order to minimize the debt service cost as well as the variability of debt service costs across the states of nature. There are no principal-agent problems. All outstanding sovereign debt matures at the end of the second period and no new debt is issued.

The timeline of events is as follows:

Period 0: The initial household's wealth and the initial value of government debt are $A_{0}=\bar{A}_{0}$ and $\mathrm{D}_{0}=\bar{D}_{0}$, respectively. The sovereign debt manager chooses the currency composition of $D_{0}$. Households decide on the currency composition of $A_{0}$.

Period 1: Exogenous output shock is realized. Exchange rate and inflation shocks are observed. The domestic bond market equilibrium rate $i^{*}$ is determined. Sovereign debt is repaid and consumption takes place. ${ }^{13}$

\section{A. Households}

The objective of households is to smooth consumption across the states of nature. A representative household maximizes a standard mean-variance utility function, does not hold cash and is not allowed to short financial assets.

\footnotetext{
${ }^{13}$ The two-period model is appropriate because we are interested in the effect of consumption-smoothing across the states of nature (not across time) on the currency composition of domestic sovereign debt.
} 
The nominal consumption $C_{t}$ in period $t$ is assumed to be a geometric average of the tradable and non-tradable consumption, where $\alpha$ is the share of tradable consumption:

$$
C_{1}=\left(C_{1}^{T}\right)^{\alpha}\left(C_{1}^{N T}\right)^{1-\alpha}
$$

The aggregate price level in period $t$ is given by:

$$
P_{t}=\frac{\left(P_{t}^{T}\right)^{\alpha}\left(P_{t}^{N T}\right)^{1-\alpha}}{\alpha^{\alpha}(1-\alpha)^{1-\alpha}}
$$

Where $P_{t}^{T}$ and $P_{t}^{N T}$ are the price levels of tradables and non-tradables, respectively. The change in the price level is $\frac{P_{1}}{P_{0}}=(1+\hat{p})$, where $\hat{p}$ is a random variable with mean $E(\hat{p})$ and variance $V(\hat{p})$. Assuming that foreign prices are constant, the change in the price level of tradables is $\frac{P_{1}^{T}}{P_{0}^{T}}=(1+\hat{s})$, where $\hat{s}$-the unexpected nominal exchange rate depreciation-is a random variable with mean $E(\hat{s})$ and variance $V(\hat{s})$.

In what follows, we make two assumptions that are consistent with the empirical evidence for EM/developing countries:

Assumption 1: We assume that $\operatorname{Cov}(\hat{s}, \hat{p})>0$, i.e., changes in the domestic price level and nominal exchange rate depreciations have positive covariance.

Households produce output $Y$, which is subject to a stationary random shock $\hat{\varepsilon}$, such that $E(\hat{\varepsilon})=0$ and $V(\hat{\varepsilon})=\sigma_{\varepsilon}^{2}$. The realized $\hat{\varepsilon}$ is positive in good states of nature and negative in bad states of nature. We assume that households pay taxes (at a rate $\tau<1$ ) and receive (make) transfers equal to $\mu \tau \hat{\varepsilon} Y_{1}$, i.e., $\mu$ times the fiscal revenue overperformance (underperformance) in good (bad) states, where parameter $\mu$ is predetermined. Note that $\mu \tau \hat{\varepsilon} Y_{1}$ can be interpreted broadly as "public goods and transfers" that provide direct utility to the households. When $\mu>0$, the transfers are pro-cyclical, i.e., the government makes positive transfers to the households in good states and negative transfers in bad states. ${ }^{14}$ This is consistent with the political economy interpretation of the procyclical fiscal policy by Alesina et al (2006), i.e.,

\footnotetext{
${ }^{14}$ As Kaminsky et al (2004), we define "cyclicality" of fiscal policy in terms of policy instruments (e.g., government spending and/or tax rates) rather than policy outcomes (e.g., fiscal balance). Hence, a procyclical fiscal policy involves higher (lower) government spending and/or lower (higher) tax rates in good (bad) times.
} 
when voters see a positive realization of the output shock, they demand immediate benefits in the form of either tax cuts or increases in public goods and transfers.

Assumption 2: We assume that $\operatorname{Cov}(\hat{s}, \hat{\varepsilon})<0$, i.e., negative (positive) output shocks are associated with nominal exchange rate depreciations (appreciations). ${ }^{15}$

The nominal wealth of a household in period $1, A_{1}$, is given by:

$$
A_{1}=\left[\delta^{*}\left(1+r^{*}\right)(1+\hat{s})+\left(1-\delta^{*}\right)(1+i)\right] A_{0}+(1-\tau)(1+\hat{\varepsilon}) Y_{1}+\mu \tau \hat{\varepsilon} Y_{1}
$$

where $\delta^{*}$ is a fraction of total wealth $A_{0}$ held in foreign currency bonds. The last two terms in (3) could be combined into $((1+\hat{\varepsilon})-(\tau+\tau(1-\mu) \hat{\varepsilon})) Y_{1}$, where $\tau+\tau(1-\mu) \hat{\varepsilon}$ is a fraction of output transferred to the government, given the realization of an output shock.

The household's optimization problem is:

$$
\begin{gathered}
\max _{\delta^{*}}\left\{E_{o}\left(c_{1}\right)-\frac{\gamma}{2} V\left(c_{1}\right)\right\} \\
\text { subject to } c_{1} \leq a_{1} \\
A_{0}=\bar{A}_{0}
\end{gathered}
$$

where $c_{1}$ and $a_{1}$ denote the real consumption and real wealth in period 1 , respectively, and $\gamma$ is the coefficient of risk aversion.

Solving (4) under the assumption that shocks $\hat{s}, \hat{\varepsilon}$, and $\hat{p}$ are small, yields the following optimal share of households' savings denominated in foreign currency ${ }^{16}$ :

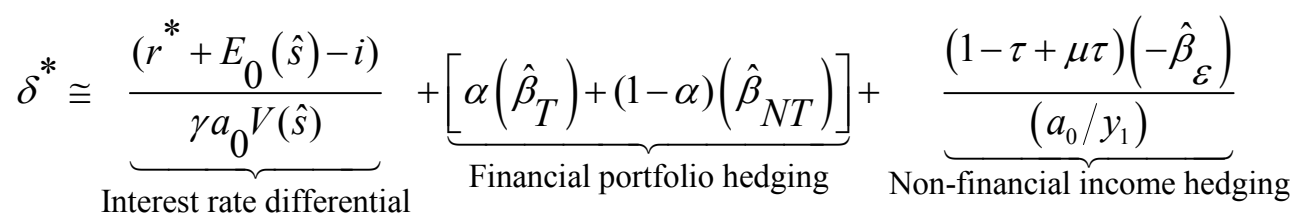

where $y_{1}$ is the real output in period 1 .

The interpretation of betas deserves special attention, as it is important for mapping the model into the data:

\footnotetext{
${ }^{15}$ See Chang and Velasco (1997), Velasco (2000), and Tornell and Velasco (2000).

${ }^{16}$ See Appendix I for details.
} 
$\hat{\beta}_{T}=\frac{\operatorname{Cov}\left(\hat{s}, \hat{p}_{T}\right)}{V(\hat{s})}$ is the correlation between unexpected changes in the nominal exchange rate and the price level of tradables (exchange rate pass-through in the tradable sector);

$\hat{\beta}_{N T}=\frac{\operatorname{Cov}\left(\hat{s}, \hat{p}_{N T}\right)}{V(\hat{s})}$ is the correlation between unexpected changes in the nominal exchange rate and the price level of non-tradables (exchange rate pass-through in the non-tradable sector);

$\hat{\beta}_{\varepsilon}=\frac{\operatorname{Cov}(\hat{s}, \hat{\varepsilon})}{V(\hat{s})}$ is the correlation between unexpected changes in the exchange rate and output.

What is the intuition behind (5)?

- $\quad$ As one would expect, the households' demand for foreign currency bonds is increasing in the interest rate differential between foreign currency bonds and local currency bonds (the first term in (5))

- $\quad$ The financial portfolio hedging demand for foreign currency bonds (the second term in (5), which can also be referred to as the "minimum variance portfolio" (MVP)) is a weighted average of the pass-through of the nominal exchange rate changes to the domestic prices in the tradable and non-tradable sectors. Given Assumption (1), the MVP term is always positive and tends to be higher in more open economies. ${ }^{17} \mathrm{It}$ should be noted that MVP term can also be written as follows:

$\frac{V(\hat{p})+\operatorname{Cov}(\hat{p}, \hat{e})}{V(\hat{p})+V(\hat{e})+2 \operatorname{Cov}(\hat{p}, \hat{e})}$, where $V(\hat{p})$ is the volatility of domestic inflation rate and $V(\hat{e})$ is the volatility of the real exchange rate ${ }^{18}$ The intuition is as follows. Since households are risk averse and care about the real value of consumption, they dislike uncertainty in the real returns on financial assets. Thus, the households would prefer to hold more foreign currency bonds if the real exchange rate (which determines the return volatility of foreign currency bonds measured in units of local consumption basket) is less volatile than the domestic price index (which determines the volatility of real return on local currency bonds).

${ }^{17}$ Note that given our assumptions, $\hat{\beta}_{T}=\frac{\operatorname{Cov}(\hat{s}, \hat{s})}{V(\hat{s})}=1$ and $\hat{\beta}_{N T}=\frac{\operatorname{Cov}\left(\hat{s}, \hat{p}^{N}\right)}{V(\hat{s})}>0$

${ }^{18}$ This expression is equivalent to the MVP term in the paper by Ize and Levy-Yeyati (2003). 
- $\quad$ The non-financial income hedging demand for foreign currency bonds (the third term in (5)) is positive because $\hat{\beta}_{\varepsilon}<0, \mu>0$ and $\tau<1$. Intuitively, because households' non-financial income is subject to a stationary random shock, households would like the return on their bond holdings to be higher in those states of nature in which their non-financial income is lower. Assuming that shocks to non-financial income are negatively (contemporaneously) correlated with the nominal exchange rate changes, $\hat{\beta}_{\varepsilon}<0$, foreign currency bonds represent a better hedge against output shocks than domestic currency bonds because in bad states of nature, because foreign currency bonds yield a higher return (in local currency terms) than local currency bonds.

Taken together, both the financial portfolio hedging and non-financial income hedging motives would tend to increase the households' incentives to hold dollar bonds, with more procyclical fiscal policy $(\mu>0)$ reinforcing such incentives.

\section{B. Fiscal Policy and Sovereign Debt Management}

The government follows a predetermined fiscal rule (described below). The sovereign debt manager has to choose the currency composition of sovereign debt, given the objectives specified by the government (also described below). There are no principal-agent problems.

The fiscal balance, $F_{1}$, is equal to tax revenues minus transfers:

$$
F_{1}=\tau(1+\hat{\varepsilon}) Y_{1}-\mu \tau \hat{\varepsilon} Y_{1}
$$

where $\tau$ is the tax rate, $Y_{1}$ is output, $\mu$ is a fiscal policy parameter.

The value of debt at the end of period 1 is

$$
D_{1}=\left(\delta^{\prime}\left(1+r^{*}\right)(1+\hat{s})+\left(1-\delta^{\prime}\right)(1+i)\right) D_{0}
$$

where $D_{t}$ is the nominal value of debt in period $t$ (in local currency terms) and $\delta^{\prime}$ is the share of debt denominated in foreign currency.

Because all outstanding debt has to be repaid at the end of period 1 and no new debt is issued, the government's budget constraint is as follows:

$$
D_{1}+G_{1} \leq F_{1}
$$

where $G_{1}$ can be thought of as some type of "fiscal buffer" that does not provide any direct utility to the households. Rearranging terms, we have the following expression: 


$$
G_{1} \leq \tau(1+\hat{\varepsilon}) Y_{1}-\mu \tau \hat{\varepsilon} Y_{1}-\left(\delta^{\prime}\left(1+r^{*}\right)(1+\hat{s})+\left(1-\delta^{\prime}\right)(1+i)\right) D_{0}
$$

We use the same price deflator as in the household's problem; and assume that the government has the same coefficient of risk-aversion, $\gamma$, as the households'. ${ }^{19}$

The debt manager chooses a share of foreign currency debt to maximize the real value of the "fiscal buffer", while minimizing its variability:

$$
\begin{aligned}
\max _{\delta^{\prime}}\left\{E\left(g_{1}\right)-\frac{\gamma}{2} \operatorname{Var}\left(g_{1}\right)\right\} & \\
\text { subject to } \mathrm{g}_{1} & \leq f_{1}-d_{1} \\
\mathrm{D}_{0} & =\bar{D}_{0}, \\
\tau & =\bar{\tau}
\end{aligned}
$$

where $g_{1}=\frac{G_{1}}{P_{1}}, f_{1}=\frac{F_{1}}{P_{1}}, d_{1}=\frac{D_{1}}{P_{1}}$; the initial level of debt stock and tax rate are given.

It is important to note that with pre-determined $\mathrm{D}_{0}=\bar{D}_{0}$ and $\tau=\bar{\tau}$, the optimization problem (10) is equivalent to the problem of minimizing the expected real debt service cost, while ensuring that the debt service burden is lower (higher) in the states of nature in which the government's ability to service debt-as reflected in the value of tax revenues net of transfersis worse (better). These objectives do, in fact, bear a close resemblance to the typical operational objectives of sovereign debt managers. ${ }^{20}$

Again, assuming that the shocks $\hat{s}, \hat{\varepsilon}$ and $\hat{p}$ are small, the solution of the debt manager's optimization problem (10) yields the following optimal share of foreign currency denominated government debt: ${ }^{21}$

\footnotetext{
${ }^{19}$ It is sensible to assume a risk-averse approach to public debt management, since all the risk is at the end transferred to tax payers. For example, Wheeler (1997) suggests that the government's risk preferences should be aligned with those of a median voter.

${ }^{20}$ For example, "the basic directive pursued by the Brazilian government for public debt management is cost minimization over the long-term, taking into consideration the maintenance of judicious levels of risks" (see IMF and World Bank publication "Guidelines for Public Debt Management" (2003)).

${ }^{21}$ See Appendix I for details.
} 


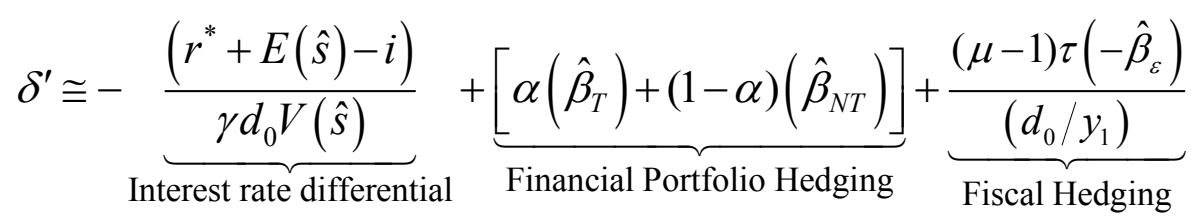

What is the intuition behind (11)?

- $\quad$ As expected, the supply of foreign currency bonds is decreasing in the interest rate differential between foreign currency and local currency bonds (the first term in (11)).

- $\quad$ The financial portfolio hedging motive for issuing foreign currency debt (the second term in (11)) is the same as in the households' problem. For the debt manager, the portfolio hedging motives are similar to those of households, because he also dislikes the volatility of the real yield on government bonds.

- $\quad$ The fiscal hedging motive for issuing foreign currency debt is represented by the last term in (11). Assume for now that $\mu=0$, then the last term reflects only the impact of the exchange rate countercyclicality on the debt manager's incentive to issue dollar debt. For $\mu=0$ and $\hat{\beta}_{\varepsilon}<0$, the last term is negative. This means that foreign currency debt is more expensive for the government than local currency debt in bad states of nature, because the yield on foreign currency bonds (expressed in local currency terms) is higher than that the yield on local currency bonds. Thus, local currency debt is a better instrument to hedge against shocks to tax revenues than foreign currency debt.

In general, the government's state-contingent ability to pay depends on the value of $\mu$. If $\mu>0$, the government follows a procyclical rule making a positive transfer to households $\mu \tau \hat{\varepsilon} Y$ given a positive realization of $\hat{\varepsilon}$ and a negative transfer $\mu \tau \hat{\varepsilon} Y$ given a negative realization of $\hat{\varepsilon}$. Consider different degrees of procyclicality:

- When $0 \leq \mu<1$, the government's ability to pay appears to be worse when foreign currency debt is more expensive. Thus, for $0 \leq \mu<1$, the last term in (11) is negative.

- When $\mu>1$, the government's ability to pay appears to be better when foreign currency debt is more expensive, because when output shock is negative, fiscal policy is tightened to more than compensate for the shortfall in fiscal revenues due to the negative output shock, thus making more revenues available for debt repayments. The latter distorts the incentives of the debt manager in favor of issuing more foreign currency debt. Thus, for $\mu>1$, the last term in (11) is positive.

The bottom line is that while financial portfolio hedging increases the debt manager's incentives to issue dollar debt, the fiscal hedging motive would likely reduce the incentives to issue dollar debt unless fiscal procyclicality is extremely strong $(\mu>1)$. 


\section{Equilibrium in the Domestic Bond Market}

In equilibrium, the demand for dollar debt by the household sector should be equal to the supply of dollar debt by the government, i.e., $\delta^{*} A_{0}=\delta^{\prime} D_{0}$. This can be further simplified by noting that the only financial assets available to households in this economy are government bonds, i.e., $A_{0}=D_{0}$. Then, the equilibrium share of foreign currency denominated sovereign $\operatorname{debt}$ (assuming that the shocks $\hat{s}, \hat{\varepsilon}$ and $\hat{p}$ are small) is given by the following expression ${ }^{22}$ :

$$
\delta^{* *} \cong \underbrace{\alpha\left(\hat{\beta}_{T}\right)+(1-\alpha)\left(\hat{\beta}_{N T}\right)}_{\begin{array}{c}
\text { Financial Portfolio } \\
\text { Hedging }
\end{array}} \underbrace{\frac{\left(\frac{1}{2}-\tau+\mu \tau\right)\left(-\hat{\beta}_{\varepsilon}\right)}{\left(d_{0} / y_{1}\right)}}_{\begin{array}{c}
\text { Non-Financial Income } \\
\text { Hedging }
\end{array}}
$$

Thus, in equilibrium, the currency composition of sovereign debt is determined by the hedging motives of the households and the sovereign debt manager.

Proposition: If the exchange rate is countercyclical $\left(\hat{\beta}_{\varepsilon}<0\right)$, fiscal policy is procyclical $(\mu>0)$ and the tax rate is $\tau<\frac{1}{2}$, the non-financial income hedging term in (12) is positive and $\delta^{* *}$ is increasing in both $\mu$ and $\left(-\hat{\beta}_{\varepsilon}\right)$, and decreasing in the sovereign debt-to-output ratio.

Thus, our model predicts that a country where exchange rate is countercyclical and fiscal policy is procyclical would have, on average, a more dollarized domestic sovereign debt. In particular, the non-financial income hedging term in (12) is positive because even for the range $0 \leq \mu<1$ (i.e., the range where households and the sovereign debt manager have opposite preferences regarding the currency denomination of debt stemming from fiscal and income hedging motives), it is dominated by the households' motive to hedge their nonfinancial income flow given that $\tau<\frac{1}{2}$ (which is a plausible assumption in the context of EM countries). Moreover, the model suggests that all else equal, the share of dollar debt would be lower for countries with higher sovereign debt-to-output ratio.

${ }^{22}$ See Appendix I for details. 


\section{TESTING THE EMPIRICAL IMPLICATIONS OF THE MODEL}

\section{A. Stylized Facts}

What is known about domestic sovereign debt structures and their determinants? Previous empirical research found the dollarization of domestic sovereign debt to be linked to certain institutional and macroeconomic features of developing countries. For example, an empirical study by Mehl and Reynaud (2008) found the domestic "original sin" to be closely related to high inflation, high debt service-to-GDP ratio and narrow investor base. Using the same dataset as the one used in this paper, Guscina (2008) showed that domestic "original sin" decreases with the level of financial development, improvement in the quality of institutions, and achievement of macroeconomic stability. The type of exchange rate regime seems to matter as well, i.e., under tightly managed exchange rate regimes debt managers tend to have less incentives to internalize exchange rate risk. To sum up, several stylized facts regarding domestic sovereign debt structures are worth highlighting:

- $\quad$ Domestic sovereign debt structures across EM and developing countries are characterized by significant heterogeneity ${ }^{23}$.

- Dollarization of domestic sovereign debt and financial dollarization (i.e., dollarization of bank loans and deposits) appear to be correlated and hence, are likely to be driven, at least in part, by common factors ${ }^{24}$.

- While both foreign currency and inflation-linked debt instruments are issued by EM sovereigns, the former appear to be more commonly used than the latter. As noted in Guscina (2008), there seems to be a certain threshold level of inflation that induces government to issue CPI-indexed debt. ${ }^{25}$

\section{B. Empirical Specification}

In our benchmark estimation, the fraction of outstanding debt denominated in dollars is regressed on variables identified in equation (12) as the main determinants of the currency composition of domestic sovereign debt. These are given by: the financial portfolio hedging term referred to as the "minimum variance portfolio" (MVP); the fiscal procyclicality term $(\mu \tau)$; the exchange rate countercyclicality term $\left(-\hat{\beta}_{\varepsilon}\right)$; the debt to GDP ratio $\left(d_{0} / y_{1}\right)$

\footnotetext{
${ }^{23}$ See Borensztein et al. (2004).

${ }^{24}$ Figure 3 at the end of the paper illustrates the relationship between sovereign debt dollarization and financial dollarization for 23 EMs.

${ }^{25}$ Figure 4 shows the evolution of domestic sovereign debt structures in selected countries in Latin America and EM Europe.
} 
capturing the size of domestic debt markets, as well as their interaction. Equation (12) can be rewritten as follows:

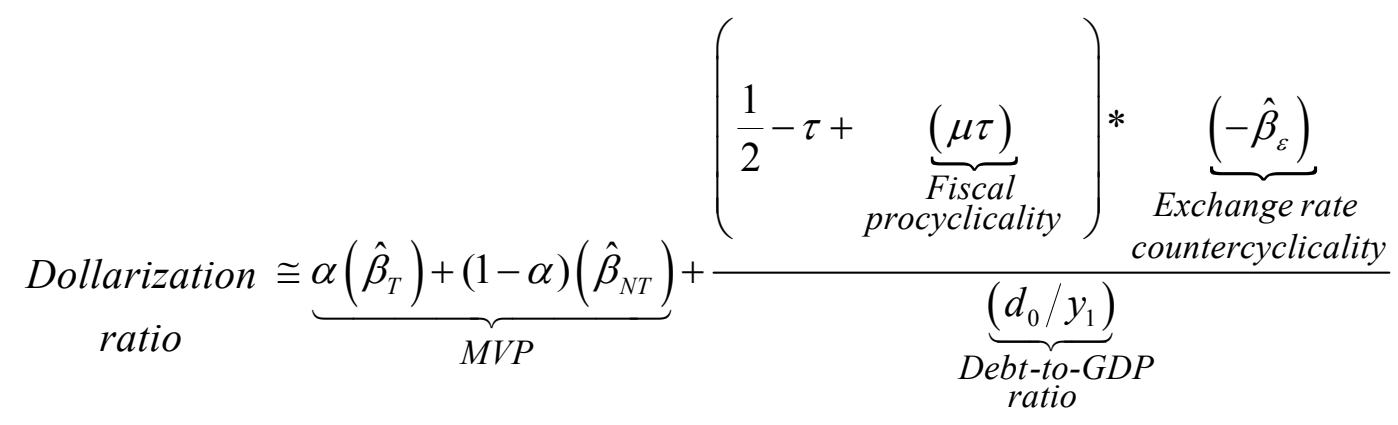

where

- $\quad$ The term $\alpha\left(\hat{\beta}_{T}\right)+(1-\alpha)\left(\hat{\beta}_{N T}\right)$ is the $M V P$, with $\hat{\beta}_{T}=\frac{\operatorname{Cov}\left(\hat{s}, \hat{p}_{T}\right)}{V(\hat{s})}$ measuring the exchange rate pass-through in the tradable sector and $\hat{\beta}_{N T}=\frac{\operatorname{Cov}\left(\hat{s}, \hat{p}_{N T}\right)}{V(\hat{s})}$ measuring the exchange rate pass-through in the non-tradable sector;

- The term $\left(-\hat{\beta}_{\varepsilon}\right)$ captures exchange-rate countercyclicality, where $\hat{\beta}_{\varepsilon}=\frac{\operatorname{Cov}(\hat{s}, \hat{\varepsilon})}{V(\hat{s})}$ is a measure of correlation between unexpected changes in the nominal exchange rate and output;

- $\quad$ The term $(\mu \tau)$ captures the degree of fiscal procyclicality.

If we assume that taxation is constant over time, then the equation (13) we need to estimate can be re-written as follows:

$$
\text { Dollarization }=M V P+\frac{(\beta+\text { Fiscal Procyclicality }) * \text { Exchange Rate Countercyclicality }}{\text { Debt }- \text { to }- \text { GDP Ratio }}
$$

Since this expression contains a triple interaction term (between fiscal procyclicality, exchange rate countercyclicality and an inverse of debt to GDP ratio), estimation results would be hard to interpret. They would also tell us little about the direct effect of exchange rate countercyclicality, fiscal procyclicality, and the debt-to-GDP ratio on the degree of sovereign domestic debt dollarization. In order to capture these direct effects, one has to derive a Taylor expansion of equation (13). Because the second order Taylor expansion would include a large number of second order derivatives and cross-derivatives and given that we have less than 400 observations, we limit the number of variables included in the regression to the minimum variance portfolio (MVP), exchange rate countercyclicality (E), 
fiscal procyclicality (F), debt- to-GDP ratio (D), and one interaction effect between exchange rate countercyclicality and fiscal procyclicality to avoid multicolinearity. This particular interaction term was chosen because we are interested in whether procyclicality of fiscal policy may lead to a more dollarized sovereign debt when the exchange rate is countercyclical.

The model that we estimate can then be written as follows:

$$
\delta_{i t}=\alpha_{1} M V P_{i t}+\alpha_{2} E_{i t}+\alpha_{3} F_{i t}+\alpha_{4} F_{i t} E_{i t}+\alpha_{5} D_{i t}+e_{i t} \quad \mathrm{i}=1, \ldots, \mathrm{N}, \mathrm{t}=1, \ldots, \mathrm{T}
$$

where $\delta$ is dollarization ratio, $E$ is exchange rate countercyclicality, $F$ is fiscal policy procylicality, and $D$ is debt to GDP ratio, $\alpha_{s}$ are coefficients or the regression and $e$ is a normally distributed disturbance with zero mean and variance $\sigma^{2}$.

The theoretical model predicts the following signs on the $\beta$ coefficients:

$\alpha_{1}>0$ : MVP should enter with a positive coefficient that is less than unity; $\alpha_{2}>0$ : countercyclicality of the exchange rate is associated with higher dollarization;

$\alpha_{4}>0$ : this is the main prior of the paper. Procyclicality of fiscal policy should lead to higher dollarization in countries where the exchange rate is more countercyclical.

$\alpha_{5}<0$ : higher debt-to-GDP ratio is associated with lower dollarization.

\section{Estimation Technique}

Because of the significant number of zero observations for the dollarization ratio in the sample, we employ a Tobit model to account for the limited dependent variable. Since the preferred specification includes the interaction term between countercyclicality of the exchange rate and the procyclicality of fiscal policy, one has to exercise caution in both estimating and interpreting the coefficient of the interaction term. We derived the correct marginal effect of the interaction term using calculus. ${ }^{26}$ The derivations of corrected coefficients in Tobit regression are in Appendix II.

\footnotetext{
${ }^{26}$ Norton, Wang, and Ai (2004) developed the inteff command in STATA to compute the correct marginal effect of a change in two interacted variables for the Probit model, as well as the correct standard errors, but such command does not exist for Tobit.
} 


\section{Data and Variable Construction}

\section{Dollarization ratio}

The dollarization ratio is defined as the ratio of foreign-currency denominated or indexed debt (both tradable/securitized and loans) issued by central governments in domestic markets.

The Jeanne-Guscina EM Debt Database (2006) was used as the main source of sovereign debt data to construct the dependent variable (the share of foreign currency debt in total domestically issued debt). This database provides annual data on the structure of central government debt in 22 emerging markets observed over a period of 25 years.

\section{Minimum Variance Portfolio}

The "minimum variance portfolio" (MVP) is a weighted average of the pass-through of the nominal exchange rate changes to the domestic prices in the tradable and non-tradable sectors. It is computed as follows:

The consumer price index (CPI) and the nominal exchange rate (defined as local currency per US dollar) come from the IFS database. We compute the real exchange rate by dividing the nominal exchange rate by the CPI. Inflation on the CPI is computed as the quarterly rate of change in the CPI inflation (log differenced). Likewise, the growth rate of the real exchange rate is computed as the log difference with respect to the previous quarter.

Then, we compute variances of inflation and real exchange rate appreciation/depreciation over samples ranging from 1 to 20 years, as well as their covariance. In our estimation, we chose MVP based on 10-year sample period, named MVP10, because of relatively short series available for the Eastern European countries in the sample. For each country in the sample we computed MVP10 using the following formula, where variances and covariances are computed over a rolling 10-year period.

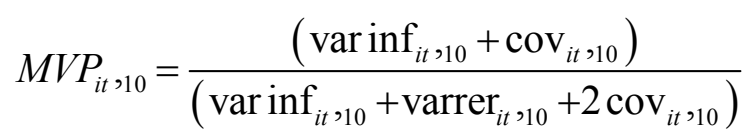

\section{Procyclicality of Fiscal Policy}

Procyclicality of fiscal policy refers to higher government spending during good times, and cuts in government spending in bad times.

To construct this variable, we first require measures of real government consumption and real GDP. We take government consumption expenditure in local currency (from IFS) and divide it by the CPI to get real government consumption. The CPI and the real GDP in local currency are taken from the World Economic Outlook database (WEO). To get a measure of 
procyclicality of fiscal policy, we estimate the OLS coefficient of the growth rate of real government consumption on the growth rate of real GDP over a moving window of 15 years using annual data. The fiscal procyclicality term is positive for most countries/time periods, as expected (see Appendix Table 4).

\section{Countercyclicality of the Exchange Rate}

Countercyclicality of exchange rate refers to currency depreciation in bad times, and currency appreciation in good times, which is a common feature of EM economies.

To obtain the measure of exchange rate countercyclicality, we regress the nominal exchange rate growth on real GDP growth over a moving window of 15 years using annual data. Nominal exchange rate (local currency per US dollar) and real GDP data are taken from WEO. After obtaining the estimated beta coefficients from the OLS rolling regression, we multiply them by $(-1)$. The exchange rate countercyclicality term is positive for most countries/time periods, as expected (see Appendix Table 3).

\section{Size of Domestic Sovereign Debt Market}

Domestically issued sovereign domestic debt- to-GDP ratio is a standard measure of the size of domestic debt market. It is taken from the Jeanne-Guscina EM Debt Database.

\section{Other Controls}

Other factors that we control for include institutional quality, the total size of the economy, and regional dummies.

Size of the Economy The size of the domestic economy is proxied by the log of real GDP. While the size of the economy is not part of our theoretical model, we still choose to control for it, in the empirical analysis. This is because previous research found that larger countries are better able to overcome domestic original sin and borrow more in their own currency than smaller countries (see, for example, Claessens, Klingebiel, and Schmukler (2007)).

\section{Institutional and Political Quality}

We also control for the quality of political institutions using the Polity 2 variable from Polity database (Jaggers and Gurr 1995; Marshall and Jaggers 2002), which captures the accountability and representativeness of the government. ${ }^{27}$ More representative political systems tend to have faster financial development, including the development of domestic debt market.

\footnotetext{
${ }^{27}$ It relies on a fairly comprehensive definition of democracy, which includes electoral rules and various measures of the openness of political institutions, and provides detailed information on aspects of institutionalized democracy and autocracy in a country at any point of time. Polity 2 is an index that varies between -10 to 10 .
} 
Hence, we control for political factors that might influence the development of domestic $\mathrm{debt}^{28}$. Our prior is that countries with better political institutions are more likely to borrow in local currency.

\section{Regional Dummies}

Finally, since Asian and Latin American countries differ significantly in the degree of sovereign debt dollarization, we include regional dummy variables to account for time invariant and unobserved factors driving regional differences in sovereign debt dollarization.

\section{E. Main Results and Robustness Tests}

Table 3 reports results for the Censored Tobit regressions on a pooled sample of 22 emerging market countries over the period of 1980-2005. The empirical results are broadly consistent with the model. First, the MVP variable has the expected positive coefficient and is statistically significant at the one percent level. Confirming our prediction, this result suggests that faced with relatively high price uncertainty, households will find it optimal to save a (possibly large) fraction of their total wealth in foreign currency to help smooth their income and consumption across states of nature. On the other hand, bond managers are likely to dollarize their debt, in an effort to denominate their liabilities in stable units of account and thus reduce the uncertainty of future outlays.

Second, our empirical estimates validate the relationship between the dollarization of debt and countercyclicality of the exchange rate. When depreciations are linked to declines in income, the dollar's value rises in bad times, providing lenders with insurance services during recessions. Thus, investors (i.e., households) may skew their investments towards the dollar because it constitutes a safe haven from economic downturns.

Third, the model's prediction that a higher debt- to-GDP ratio would lower the degree of dollarization is confirmed as well. This is consistent with the view that issuers face a tradeoff between getting access to less expensive capital via bonds issuance and avoiding potential currency mismatches. As the local market expands and the ability to issue in one's own currency improves, issuers tend to favor own currency liabilities over the foreign marketcurrency alternative. ${ }^{29}$

\footnotetext{
${ }^{28}$ For literature on the link between financial development and political regime see Rajan and Zingales (2003), Perotti and Volpin (2007), and Girma and Shortland (2005).

${ }^{29}$ There is another interpretation of the negative association between the government debt to GDP ratio and dollarization of sovereign debt. Because both high level of sovereign debt and high level of dollarization increase the risk of default, to the extent that the EM governments care about minimizing such risk they would try to avoid having both high government debt-to-GDP ratio and a large share of dollar debt.
} 
Fourth, our model suggests that the degree of procyclicality of fiscal policy by itself does not have an impact on the dollarization of sovereign debt, but that it affects debt dollarization through its interaction with exchange rate countercyclicality. We found strong empirical support for both predictions. First, the coefficient on fiscal policy procyclicality is not statistically significant. Second, the coefficient on the interaction term between fiscal procyclicality and exchange rate countercyclicality is positive and statistically significant. That is, the positive effect of the nominal exchange rate countercyclicality on the dollarization of government debt is amplified in cases where fiscal policy is procyclical. The effective parameter (or total effect) of exchange rate countercyclicality in the model (equal to $\alpha_{2}+\alpha_{4} F$ ) is presented in Figure 5 .

Fifth, the empirical estimation also confirms that the fraction of bonds issued in foreign currency is significantly and negatively correlated with the size of the overall domestic debt market, which is also consistent with our model. Bigger economies are less subjected to both international and domestic "original sin", and more likely to borrow in their local currencies. These results are consistent with Claessens, Klingebiel, and Schmukler (2007), who found that bigger countries have larger domestic currency bond markets, and issue more debt in local currency. We also find that countries with better political institutions are more likely to borrow in local currency. ${ }^{30}$ This is consistent with findings of Mehl and Reynaud (2008), Guscina (2008), and others.

\section{Robustness Checks}

As learned from debt crises of the past decades, higher shares of dollarized debt have important implications for the probability and severity of crises. Highly dollarized debt structure might make a country more prone to both currency and debt crises, which in turn might lead to economic contractions and a cut in government spending. While the causality might go from degree of dollarization to procyclicality of fiscal policy, we believe that this direction would be more explicit during the times of currency crises. Thus, we first controlled for currency crises by including dummy variables for periods of turmoil in currency or debt markets, and second by limiting the sample to tranquil times. However, including currency crises or debt crisis dummies, or limiting the sample to only calm times, did not alter the results. We still find that procyclicality of fiscal policy reinforces incentives to dollarize dollar debt when exchange rate is countercyclical even in periods with no turmoil in currency markets.

We also investigated whether our results hold for a shorter, more recent period, where the quality of the data is likely to be better. Restricting the sample to 1987-2005 yielded very

\footnotetext{
${ }^{30}$ The results are robust to using other measures of institutional quality such as ICRG index or the composite index of regulatory quality compiled by Kaufmann et al. (2005).
} 
similar results. We also tried to address possible endogeneity issues by including one year lags of fiscal procyclicality and exchange rate countercyclicality (and their interaction) instead of contemporaneous values. The results still hold. The results of these robustness checks are summarized in Table 4.

\section{CONCluding Remarks}

This paper explores the link between exchange rate countercyclicality, fiscal procyclicality and the level of dollarization of domestic sovereign debt (i.e., debt issued in national jurisdictions) in emerging market countries. The empirical analysis is informed by the equilibrium model, in which the dollarization of sovereign debt arises as a result of the optimal portfolio choices by risk-averse investors and risk-averse sovereign debt managers. Consistent with the predictions of the model, the empirical analysis using the data for $22 \mathrm{EM}$ countries over the period 1980-2005 confirms that

- $\quad$ Countries where the real exchange rate is less volatile than the domestic inflation rate have, on average, a more dollarized domestic sovereign debt.

- $\quad$ Countries where exchange rate is countercyclical (i.e., the exchange rate depreciates during recessions) have, on average, a more dollarized domestic sovereign debt.

- $\quad$ Countries where exchange rate is countercyclical, a more procyclical fiscal policy (i.e., expansionary in booms and contractionary during busts) leads, on average, to a more dollarized domestic sovereign debt.

These findings have several implications for the discussion on the pre-conditions for developing local currency bond markets:

- A combination of flexible exchange rate regime and inflation targeting would reduce the relative volatility of inflation to exchange rate changes and hence, the share of foreign currency denominated instruments in domestic debt markets.

- If the exchange rate is highly countercyclical, reducing fiscal procyclicality may help countries the incentives to dollarize domestic sovereign debt.

Finally, we find that countries with smaller public debt- to-GDP ratios tend to have higher levels of foreign currency domestic sovereign debt. This finding appears to be line with the evidence that past debt de-dollarization processes have been associated with deepening of domestic markets (Bordo et al., 2005), and that dollarization of sovereign debt is negatively related to the size of domestic financial markets (Claessens et al., 2007, Eichengreen et al., 2003). 


\section{References}

Adler, Gustavo, 2008, "Original Sin and Procyclical Fiscal Policy: Two Sides of the Same Coin?” IMF Working Papers, 08/209, pp. 1-27.

Alesina, Alberto, Silvia Ardagna, and Francesco Trebbi, 2006, "Who Adjusts and When? On the Political Economy of Reforms,” NBER Working Papers 12049 (Cambridge, Massachusetts: National Bureau of Economic Research).

Bordo, Michael D., and Christopher M. Meissner, 2005, "The Role of Foreign Currency Debt in Financial Crises: 1880-1913 vs. 1972-1997,” NBER Working Paper No. 11897 (Cambridge, Massachusetts: National Bureau of Economic Research). , and Angela Redish, 2005, “How 'Original Sin' Was Overcome: The Evolution of External Debt Denominated in Domestic Currencies in the United States and the British Dominions 1800-2000," in Barry Eichengreen and Ricardo Hausmann (Eds.), Other People's Money (Chicago: University of Chicago Press), pp. 122-153.

Borensztein, Eduardo, Marcos Chamon, Olivier Jeanne, Paolo Mauro, and Jeromin Zettelmeyer, 2004, "Sovereign Debt Structure for Crisis Prevention", IMF Occasional Paper No.237 (Washington: International Monetary Fund).

Calvo, Guillermo, 1980, “Tax-Financed Government Spending in Neoclassical Model with Sticky Wages and Rational Expectations," Journal of Economic Dynamics and Control, February 1980.

_- and Pablo Guidotti, 1990, "Indexation and Maturity of Government Bonds: An Exploratory Model," in R. Dornbushch, and M. Draghi, (eds.) Capital Markets and Debt Management; (Cambridge, Massachusetts: Cambridge University Press).

Chang, Roberto and Velasco, Andrés, 1997, "Financial Fragility and the Exchange Rate Regime," FRB Atlanta Working Paper No. 97-16 and NBER Working Paper No. 6469 (Cambridge, Massachusetts: National Bureau of Economic Research).

Chamon, Marcos, 2003, "Why Can't Developing Countries Borrow from Abroad in Their Currency?" Mimeo. (Washington: International Monetary Fund).

Claessens, Stijn, Daniela Klingebiel, and Sergio Schmukler, 2007, "Government Bonds in Domestic and Foreign Currency: The Role of Macroeconomic and Institutional Factors," Review of International Economics, 15:2, pp. 370-413.

Eichengreen, Barry, Ricardo Hausmann, and Ugo Panizza, 2003, "Currency Mismatches, Debt Intolerance and Original Sin: Why They are Not the Same and Why it Matters," NBER No.10036 (Cambridge, Massachusetts: National Bureau of Economic Research). 
Girma, S. and A. Shortland, 2005, "The Political Economy of Financial Liberalisation," Working Paper No. 12/05 (Leicester, United Kingdom: University of Leicester).

Guscina, Anastasia, 2008, "Impact of Macroeconomic, Political, and Institutional Factors on the Structure of Government Debt in Emerging Market Countries," IMF Working Paper 08/205 (Washington: International Monetary Fund).

Hausmann, Ricardo and Ugo Panizza, 2003, “The Mystery of Original Sin,” IMF Research Paper No. 2003164B: (Washington: International Monetary Fund, August).

Ilzetzki, Ethan and Carlos Vegh, 2008, "Procyclical Fiscal Policy in Developing Countries: Truth of Fiction?," NBERWorking Papers 14191 (Cambridge, Massachusetts: National Bureau of Economic Research).

International Monetary Fund and World Bank, 2003, Guidelines for Public Debt Management: Accompanying Document and Selected Case Studies (Washington: IMF).

Ize, Alain, 2005, "Financial Dollarization Equilibria: A Framework for Policy Analysis," IMF Working Paper 05/186 (Washington: International Monetary Fund).

—, and Eduardo Levy-Yeyati, 2003, "Financial Dollarization,” Journal of International Economics, Vol. 59, pp. 32347.

Jaggers, Keith and Ted Robert Gurr, 1995, “Tracking Democracy's Third Wage with the Polity III Database,” Journal of Peace Research, Vol. 32, No. 4, pp. 469-482.

Jeanne, Olivier, 2000, "Foreign Currency Debt and the Global Financial Architecture," European Economic Review, Vol. 44, No. 46 (May), 719-727.

— 2004, “Debt Maturity and the International Financial Architecture," IMF Working Paper 04/137 (Washington: International Monetary Fund).

— New Data Set,” IMF Working Paper 06/98 (Washington: International Monetary Fund).

Kaminsky, G., C. Reinhart, and C. Vegh, 2004, "When It Rains, It Pours: Procyclical Capital Flows and Macroeconomic Policies”, NBER Working Paper No. 10780 (Cambridge, Massachusetts: National Bureau of Economic Research).

Kaufmann, Daniel, Aart Kray, and Massimo Matruzzi, 2005, “Governance Matters IV: Governance Indicators for 1996-2004,” Policy Research Working Paper No. 3630, June 2005 (Washington: The World Bank). 
Lane, Philip and Aaron Tornell, 1999, "The Voracity Effect", American Economic Review, 89, 22-46, March 1999.

Lane, Philip R. and Shambaugh, Jay C., 2010, “The Long or Short of It: Determinants of Foreign Currency Exposure in External Balance Sheets", Journal of International Economics, Volume 80, Issue 1, pp. 33-44.

Marshall, M. and K. Jaggers, 2002, "Polity IV Project: Political Regime Characteristics and Transitions, 1800-2002," http://www.bsos.umd.edu/cidcm/polity/

Mehl, Arnaud and Julien Reynaud, 2008, "The Domestic Debt Structures in Emerging Markets: New Empirical Evidence," Documents de travail du Centre d'Economie de la Sorbonne, Universite Pantheone-Sorbonne (Paris 1).

Norton, E., H. Wang, and C. Ai, 2004, "Computing Interaction Effects and Standard Errors in Logit and Probit Models," The Stata Journal, Vol. 4, No. 2, pp. 154-167.

Perotti, E., and Volpin, P., 2007, "Politics, Investor Protection and Competition," Amsterdam University Business School Working Paper (Amsterdam, Netherlands: Amsterdam University Business School).

Rajan R., and L. Zingales, 2003, "The Great Reversals: The Politics of Financial Development in the Twentieth Century," Journal of Financial Economics, Vol. 69 (July) pp. 5-50.

Riascos, Alvaro and Carlos Vegh, 2003, "Procyclical Fiscal Policy and Developing Countries: The Role of Incomplete Markets" (mimeo, UCLA and Banco Republica, Colombia).

Reinhart, C., and K. Rogoff, 2008, "The Forgotten History of Domestic Debt," NBER Working Paper No. 13946 (Cambridge, Massachusetts: National Bureau of Economic Research).

Talvi, E., and C. Vegh, 2005, "Tax Base Variability and Procyclical Fiscal Policy in Developing Countries," Journal of Development Economics, Vol.78, No.1, pp.15690.

Tirole, Jean, 2002, Financial Crises, Liquidity and the International Monetary System (Princeton: Princeton University Press).

Tornell, Aaron and Andres Velasco, 2000, "Fixed Versus Flexible Exchange Rates: Which Provides More Fiscal Discipline?" Journal of Monetary Economics, Vol. 45, Issue 2, April 2000, pp. 399-436. 
Velasco, Andres, 2000, "Debt and Deficits under Fragmented Fiscal Policymaking," Journal of Public Economics, Vol. 76, Issue 1, April 2000, pp. 105-125.

Wheeler, G., 1997, "New Zealand's Experience with Autonomous Sovereign Debt Management," Risk Management Fore Sovereign Countries (Washington: International Monetary Fund). 
Figure 1: Exchange Rate Countercyclicality

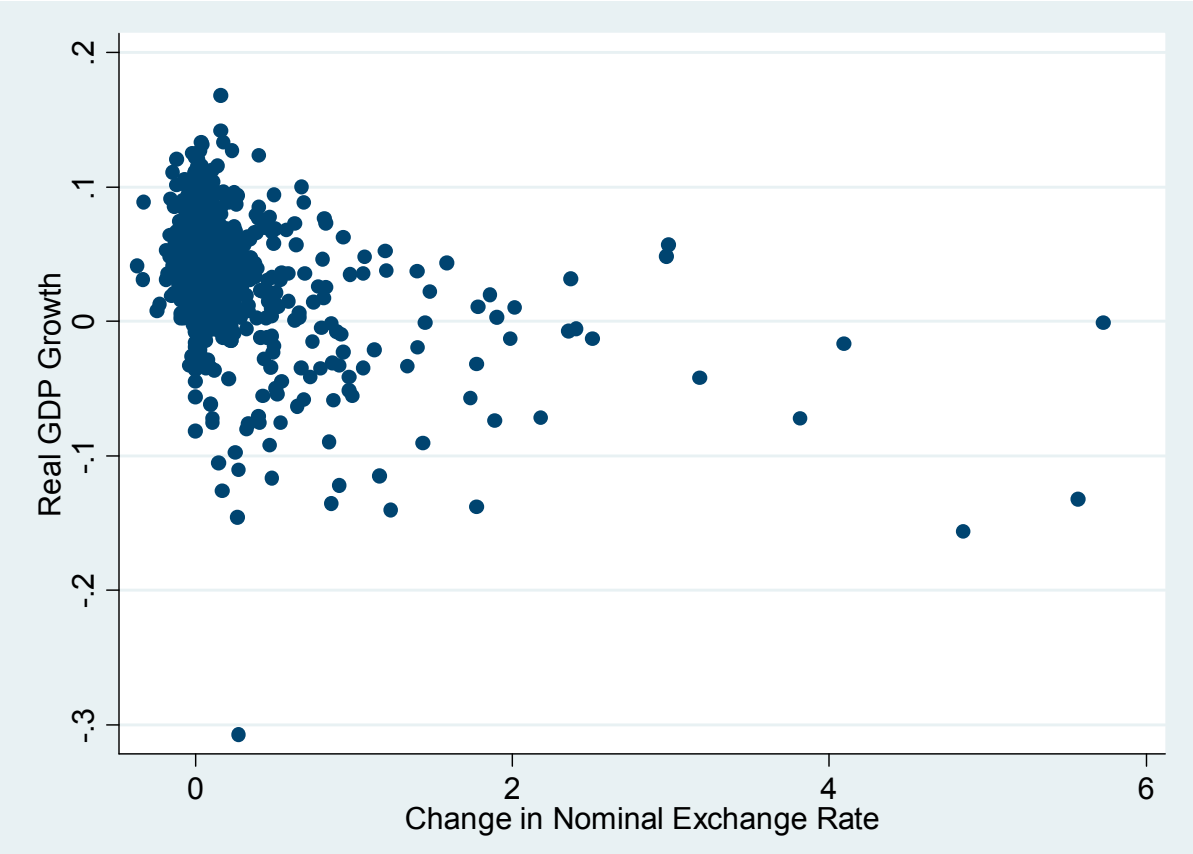

Source: World Economic Outlook.

Figure 2: Fiscal Procyclicality

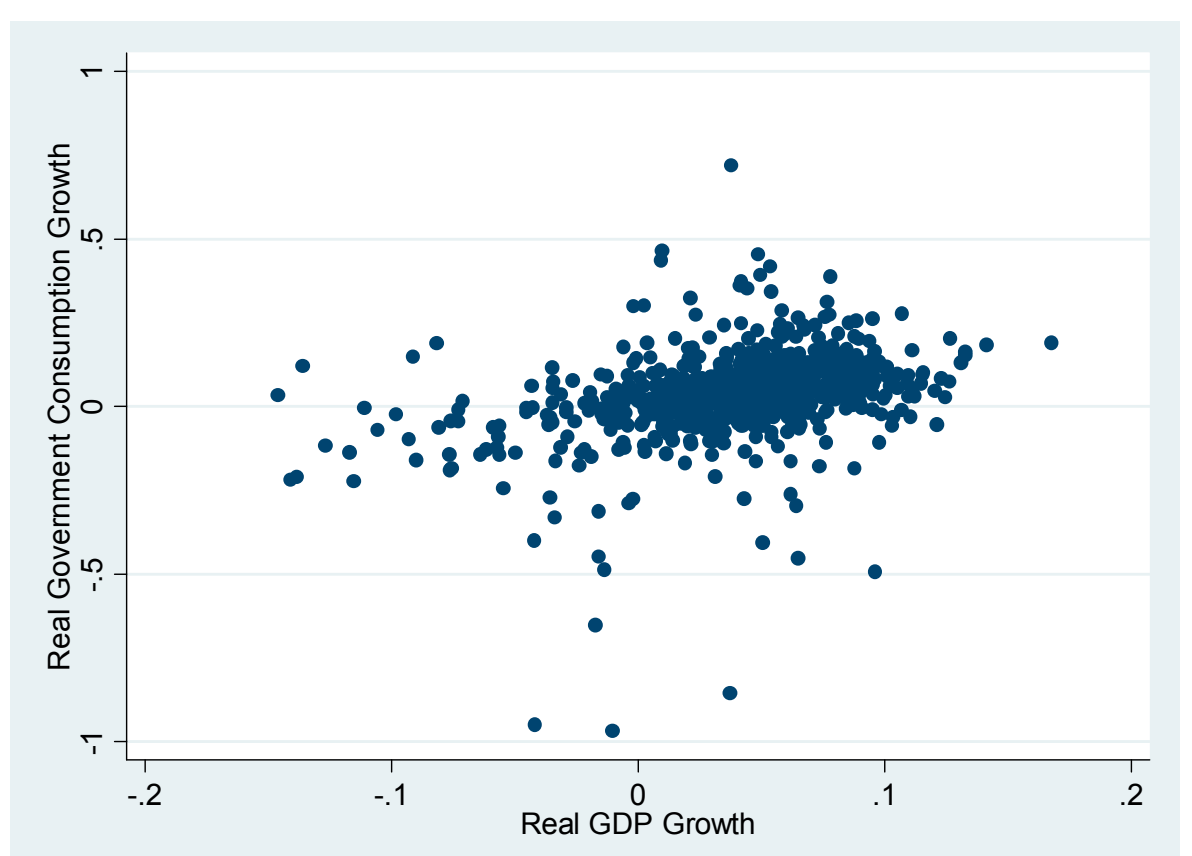

Source: World Economic Outlook and International Financial Statistics. 
Figure 3: Dollarization of Sovereign Debt and Dollarization of Bank Loans \& Deposits
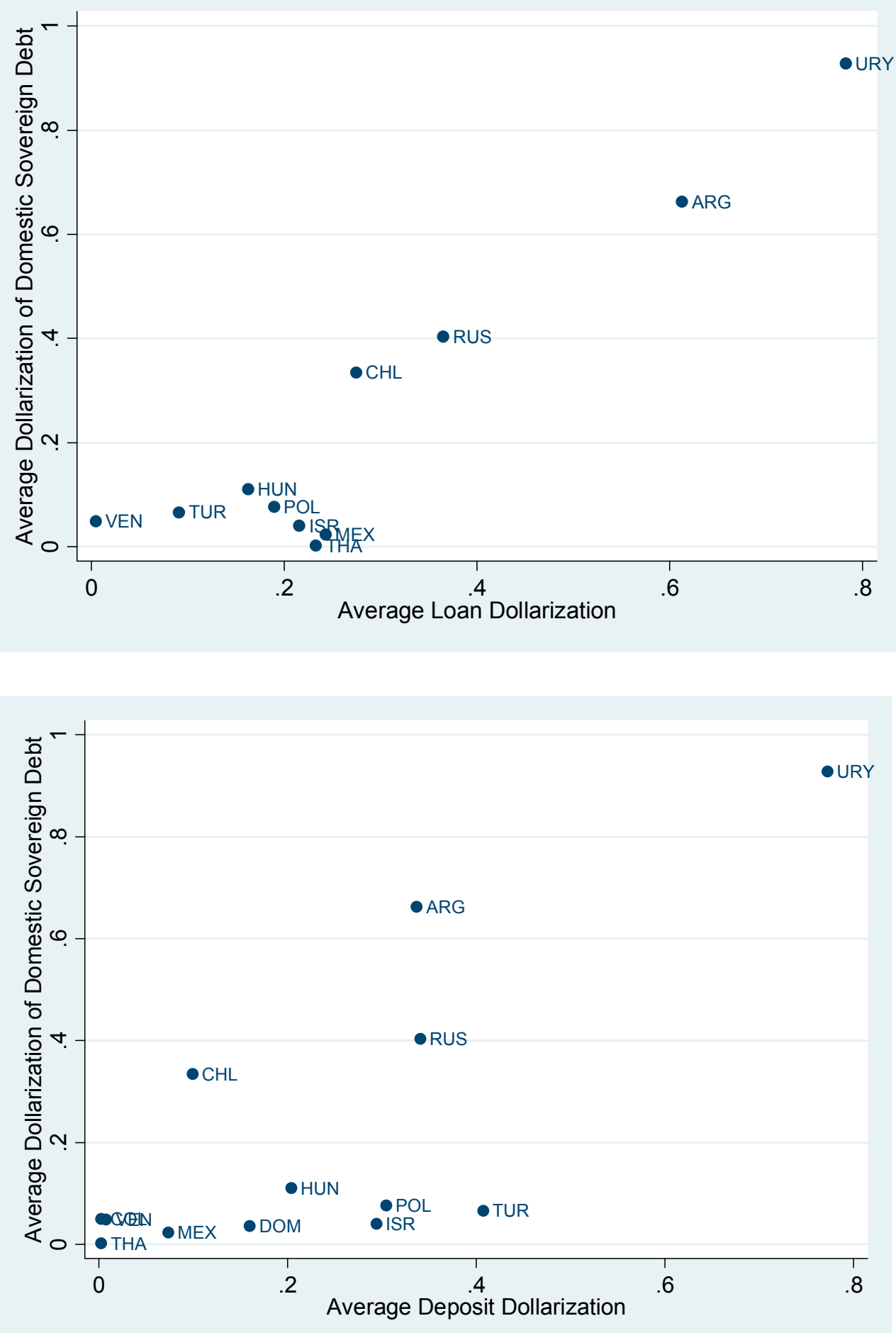

Source: Jeanne-Guscina EM Debt Database (2006). 
Figure 4a. Latin America-Domestic Sovereign Debt Structure-Selected Countries (In percent of total domestic debt, in USD)

$\square$ Foreign Currency debt $\square$ Indexed Debt Local Currency Debt

ARGENTINA

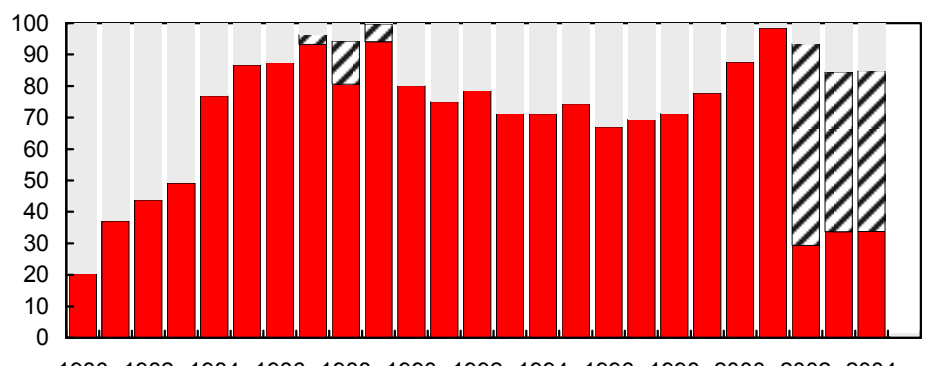

BRAZIL

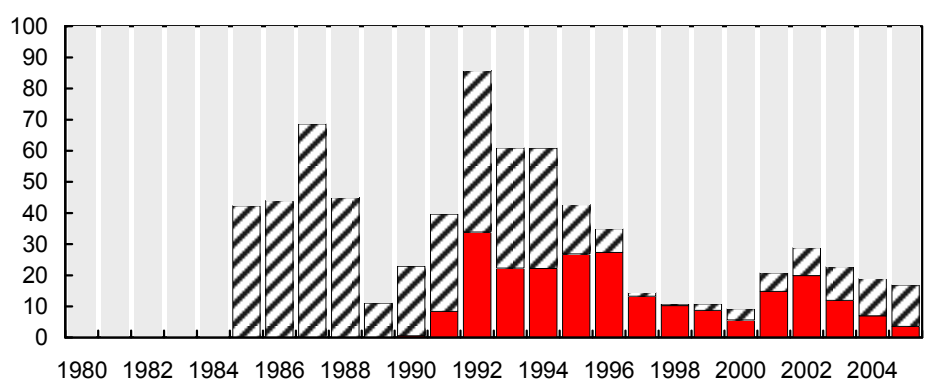

CHILE

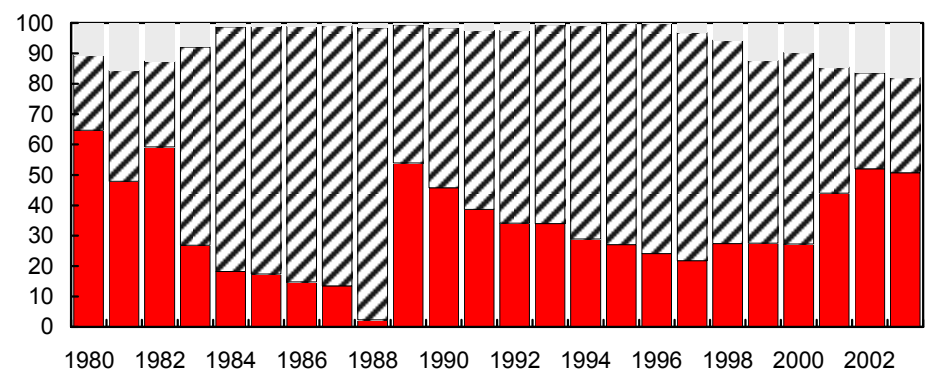

MEXICO

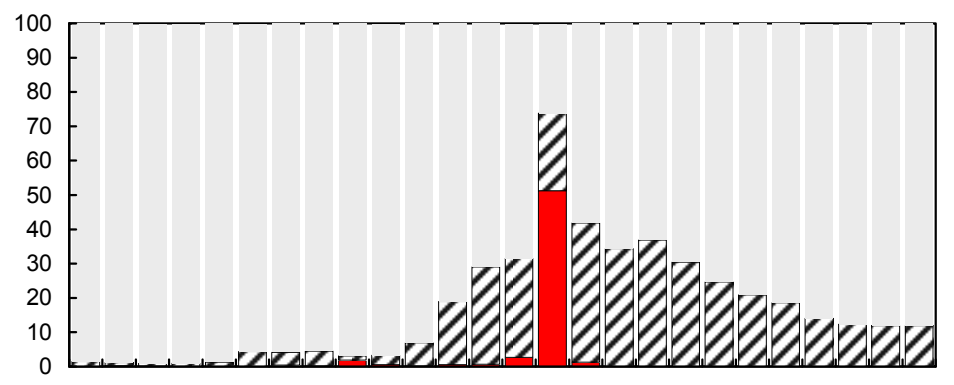

1980198219841986198819901992199419961998200020022004

Source: Jeanne-Guscina EM Debt Database (2006). 
Figure 4b. EM Europe-Domestic Sovereign Debt Structures-Selected Countries (In percent of total domestic debt, in USD)

$\square$ Foreign Currency Debt $\square$ Indexed Debt Local Currency Debt

HUNGARY
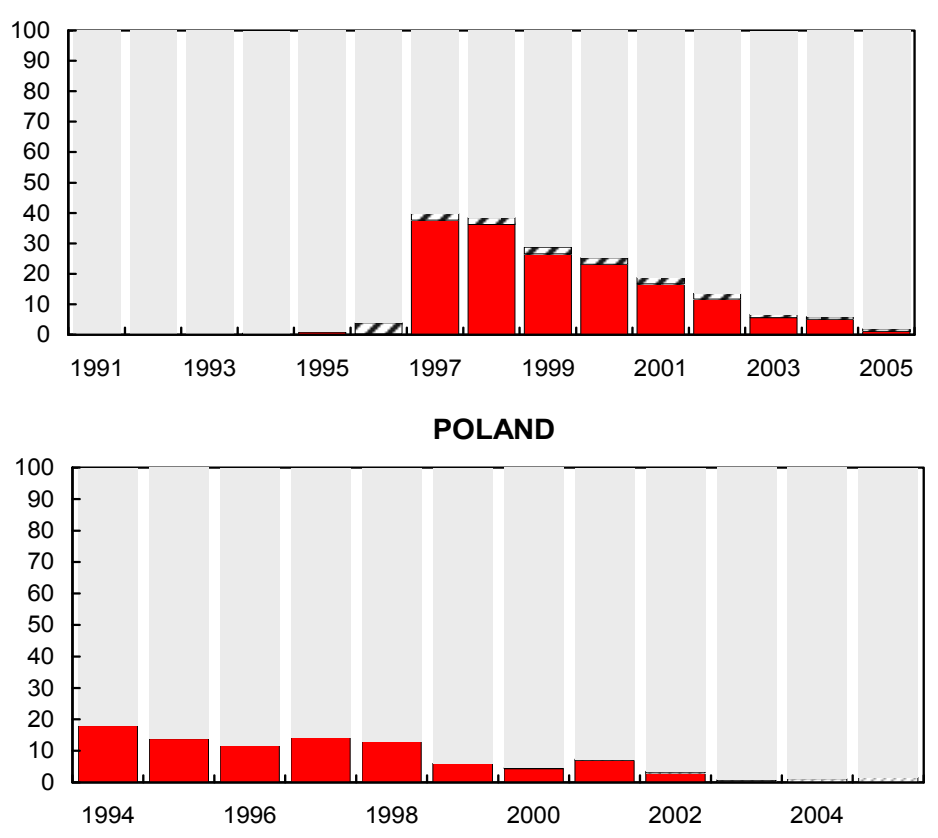

RUSSIA
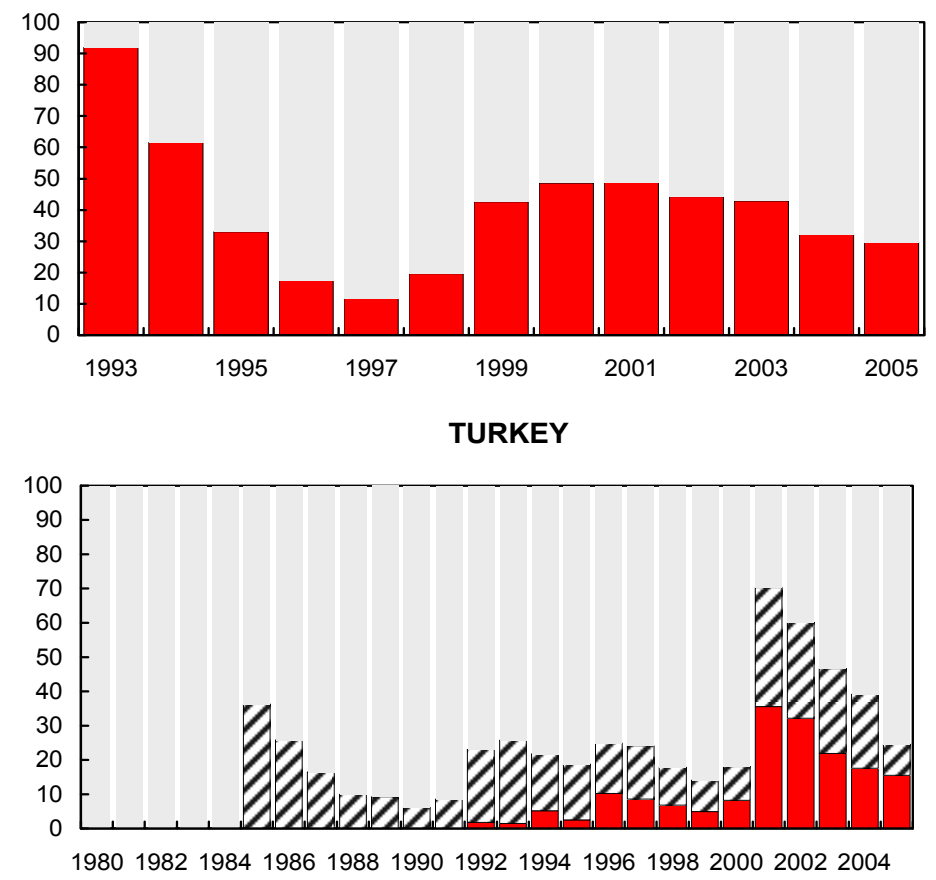

Source: Jeanne-Guscina EM Debt Database (2006). 
Figure 5. Effect of Countercyclicality of the Exchange Rate on Dollarization of Sovereign Debt, for Different Levels of Fiscal Procyclicality

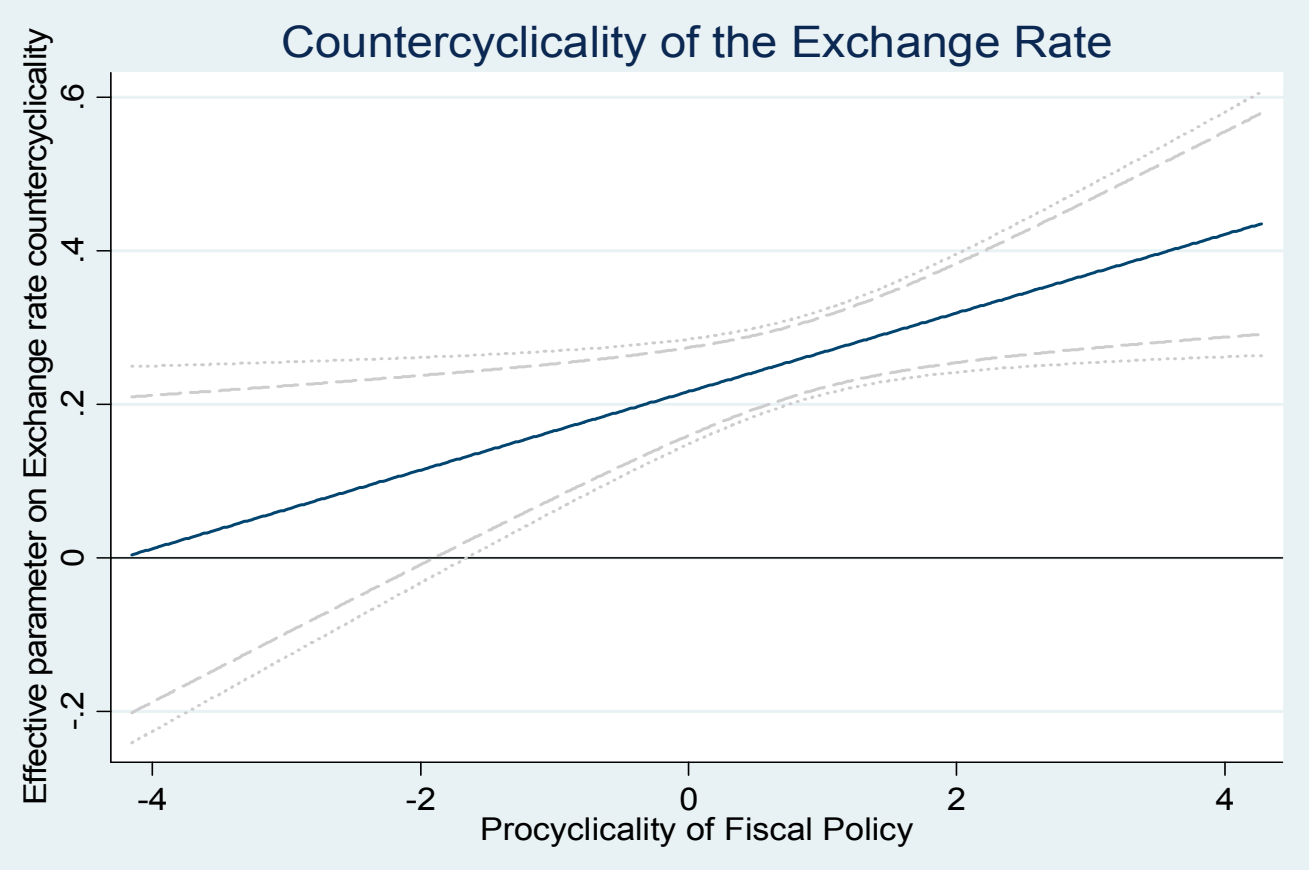

Source: Authors' calculations. 
Table 1. Countercyclicality of the Exchange Rate: Summary Statistics

\begin{tabular}{|c|c|c|c|c|}
\hline Country & Obs & $\begin{array}{r}\text { Std. } \\
\text { Deviation } \\
\end{array}$ & Min & Max \\
\hline Argentina & 22 & 41.326 & 4.272 & 124.889 \\
\hline Brazil & 21 & 23.701 & 5.758 & 77.031 \\
\hline Chile & 22 & 5.017 & 0.71 & 13.733 \\
\hline Colombia & 22 & 0.665 & -0.399 & 2.353 \\
\hline Costa Rica & 22 & 2.678 & 0.668 & 6.715 \\
\hline $\begin{array}{l}\text { Czech Republic } \\
\text { Dominican }\end{array}$ & 22 & 3.497 & -0.127 & 9.072 \\
\hline Rep. & 22 & 2.482 & -0.124 & 10.751 \\
\hline Guatemala & 21 & 3.956 & -0.542 & 16.956 \\
\hline Hungary & 21 & 0.556 & -0.084 & 1.59 \\
\hline India & 22 & 1.493 & -0.951 & 3.513 \\
\hline Indonesia & 22 & 4.243 & 1.729 & 11.324 \\
\hline Israel & 22 & 8.207 & 0.387 & 22.004 \\
\hline Korea & 22 & 0.605 & 1.331 & 3.332 \\
\hline Mexico & 22 & 2.344 & 4.9 & 11.945 \\
\hline Malaysia & 22 & 0.682 & 0.124 & 1.913 \\
\hline Philippines & 22 & 0.357 & 1.188 & 3.354 \\
\hline Poland & 22 & 7.872 & -0.342 & 20.256 \\
\hline Thailand & 22 & 0.457 & 0.356 & 1.897 \\
\hline Turkey & 22 & 1.197 & 3.798 & 7.857 \\
\hline Uruguay & 22 & 1.328 & -1.356 & 4.903 \\
\hline Venezuela & 22 & 1.703 & 0.117 & 6.202 \\
\hline South Africa & 22 & 1.207 & -1.7 & 2.452 \\
\hline
\end{tabular}

Source: Authors' calculations. 
Table 2. Procyclicality of Fiscal Policy: Summary Statistics

\begin{tabular}{|c|c|c|c|c|}
\hline Country & Obs & $\begin{array}{r}\text { Std. } \\
\text { Deviation }\end{array}$ & Min & Max \\
\hline Argentina & 22 & 1.182 & 0.211 & 4.239 \\
\hline Brazil & 17 & 0.88 & 0.636 & 3.224 \\
\hline Chile & 22 & 0.265 & 0.339 & 1.372 \\
\hline Colombia & 22 & 0.637 & 0.458 & 2.768 \\
\hline Costa Rica & 22 & 0.631 & 0.643 & 2.402 \\
\hline Czech Republic & 4 & 0.182 & 0.67 & 1.096 \\
\hline Dominican Rep. & 22 & 1.247 & -2.556 & 1.97 \\
\hline Guatemala & 21 & 0.475 & 0.417 & 2.649 \\
\hline Hungary & 21 & 0.216 & 0.197 & 0.992 \\
\hline India & 22 & 0.627 & -0.53 & 1.795 \\
\hline Indonesia & 22 & 0.452 & 0.025 & 1.847 \\
\hline Israel & 22 & 0.978 & 0.479 & 4.272 \\
\hline Korea & 22 & 0.347 & -0.893 & 0.438 \\
\hline Mexico & 22 & 0.377 & 1.31 & 2.65 \\
\hline Malaysia & 22 & 0.263 & 0.014 & 1.093 \\
\hline Philippines & 22 & 0.335 & 1.12 & 2.241 \\
\hline Poland & 17 & 1.791 & -4.152 & 1.875 \\
\hline Russia & 5 & 0.096 & 0.382 & 0.637 \\
\hline Thailand & 22 & 0.576 & 0.001 & 1.969 \\
\hline Turkey & 22 & 0.441 & 0.18 & 1.696 \\
\hline Uruguay & 22 & 0.163 & 0.373 & 0.971 \\
\hline Venezuela & 22 & 0.943 & 0.874 & 3.502 \\
\hline South Africa & 22 & 0.177 & 0.524 & 1.256 \\
\hline
\end{tabular}

Source: Authors' calculations. 
Table 3. Results of Censored Tobit Estimation- Pooled Data: 1980-2005 (Coefficient and standard error)

\begin{tabular}{|c|c|c|c|c|c|c|c|}
\hline \multirow[t]{2}{*}{ Dependent Variable: } & \multicolumn{7}{|c|}{ Share of Dollar Debt in Domestic Debt } \\
\hline & (1) & $(2)$ & (3) & (4) & (5) & (6) & (7) \\
\hline Minimum Variance & $0.578^{* * *}$ & $0.575^{\star * *}$ & $0.594^{* * *}$ & $0.568^{\star * *}$ & $0.507^{* * *}$ & $0.510^{* * *}$ & $0.253^{* * *}$ \\
\hline Portfolio & -0.071 & -0.072 & -0.071 & -0.072 & -0.053 & -0.055 & -0.041 \\
\hline Procyclicality & & 0.687 & 0.986 & -0.033 & 0.19 & 0.236 & -0.361 \\
\hline of Fiscal Policy & & -1.111 & -1.079 & -0.449 & -0.594 & -0.623 & -0.488 \\
\hline Countercyclicality & $0.193^{* * *}$ & $0.190^{* * *}$ & $0.166^{* * *}$ & $0.061^{* * *}$ & $0.107^{* * *}$ & $0.107^{* * *}$ & $0.104^{* * *}$ \\
\hline of Exchange Rate & -0.047 & -0.046 & -0.046 & -0.015 & -0.022 & -0.022 & -0.01 \\
\hline \multirow{2}{*}{$\begin{array}{l}\text { Domestic Debt-to- } \\
\text { GDP }\end{array}$} & & & $-0.166^{* *}$ & $-0.147^{* *}$ & $-0.168^{* *}$ & $-0.177^{* *}$ & $-0.247^{* * *}$ \\
\hline & & & -0.075 & -0.075 & -0.066 & -0.09 & -0.077 \\
\hline \multirow[t]{2}{*}{ Interaction Term } & & & & $0.024^{* * *}$ & $0.030^{* *}$ & $0.030^{* *}$ & $0.021^{* *}$ \\
\hline & & & & -0.005 & -0.013 & -0.013 & -0.01 \\
\hline \multirow[t]{2}{*}{ Size of Economy } & & & & & $-5.471^{* * *}$ & $-5.448^{* * *}$ & $-3.573^{* * *}$ \\
\hline & & & & & -1.091 & -1.155 & -0.923 \\
\hline \multirow[t]{2}{*}{ Institutional Quality } & & & & & & -0.067 & $-1.349^{* * *}$ \\
\hline & & & & & & -0.328 & -0.361 \\
\hline \multirow[t]{2}{*}{ Latin America dummy } & & & & & & & $26.957^{* * *}$ \\
\hline & & & & & & & -4.748 \\
\hline \multirow[t]{2}{*}{ Asian dummy } & & & & & & & $-27.51^{* * *}$ \\
\hline & & & & & & & -4.111 \\
\hline \multirow[t]{2}{*}{ Constant } & $-19.41^{* * *}$ & $-20.01^{* * *}$ & $-15.95^{* * *}$ & $-13.19^{* * *}$ & $14.82^{* * *}$ & $14.71^{* *}$ & $12.989^{* *}$ \\
\hline & -2.796 & -2.897 & -3.308 & -3.283 & -6.531 & -6.832 & -6.273 \\
\hline Observations & 392 & 392 & 390 & 390 & 390 & 390 & 390 \\
\hline LogLik & -1145.9 & -1145.8 & -1138.79 & -1136.72 & -1094.86 & -1094.83 & -1032.15 \\
\hline $\mathrm{F}$ & 70.42 & 47.86 & 39.11 & 55.96 & 71.66 & 61.7 & 71.02 \\
\hline Pseudo $\mathrm{R}^{2}$ & 0.047 & 0.047 & 0.049 & 0.051 & 0.086 & 0.086 & 0.138 \\
\hline
\end{tabular}

Source: Authors' estimations. 
Table 4. Robustness Checks for Censored Tobit Estimation: 1980-2005 (Coefficient and standard error)

\begin{tabular}{|c|c|c|c|c|c|c|}
\hline & $\begin{array}{c}\text { (1) } \\
\text { Baseline } \\
\text { specification }\end{array}$ & $\begin{array}{c}(2) \\
\text { w/ currency } \\
\text { crisis dummy }\end{array}$ & $\begin{array}{c}\text { (3) } \\
\text { w/debt crisis } \\
\text { dummy }\end{array}$ & $\begin{array}{c}(4) \\
\text { Year>1986 }\end{array}$ & $\begin{array}{c}\text { (5) } \\
\text { w/lagged } F \\
\text { and } E\end{array}$ & $\begin{array}{c}\text { (6) } \\
\text { w/ E regime } \\
\text { dummy }\end{array}$ \\
\hline Minimum Variance & $0.253^{\star \star \star}$ & $0.238^{* * *}$ & $0.245^{\star \star \star}$ & $0.233^{* * *}$ & $0.268^{* * *}$ & $0.255^{\star * *}$ \\
\hline Portfolio & -0.041 & -0.041 & -0.041 & -0.038 & -0.04 & -0.041 \\
\hline Procyclicality of Fiscal & -0.361 & -0.356 & -0.436 & -0.601 & -0.398 & -0.353 \\
\hline Policy & -0.488 & -0.489 & -0.491 & -0.515 & -0.497 & -0.515 \\
\hline Countercyclicality of & $0.104^{\star \star \star}$ & $0.105^{\star \star *}$ & $0.103^{\star * *}$ & $0.106^{* * *}$ & $0.096^{* * *}$ & $0.105^{* * *}$ \\
\hline Exchange Rate & -0.01 & -0.01 & -0.01 & -0.011 & -0.01 & -0.01 \\
\hline Interaction Effect & $0.021^{* *}$ & $0.021^{* *}$ & $0.021^{\star *}$ & $0.029^{* * *}$ & $0.027^{* \star *}$ & $0.021^{* * *}$ \\
\hline$\left(E^{*} F\right)$ & -0.01 & -0.009 & -0.01 & -0.01 & -0.01 & -0.009 \\
\hline Domestic Debt -to-GDP & $-0.247^{\star \star *}$ & $-0.238^{\star * *}$ & $-0.234^{\star \star \star}$ & $-0.212^{\star *}$ & $-0.263^{\star \star \star}$ & $-0.247^{\star * *}$ \\
\hline Ratio & -0.077 & -0.077 & -0.076 & -0.085 & -0.076 & -0.077 \\
\hline \multirow[t]{2}{*}{ Size of Economy } & $-3.573^{* * *}$ & $-3.668^{* * *}$ & $-3.706^{\star \star *}$ & $-4.701^{* * *}$ & $-3.728^{* * *}$ & $-3.611^{* *}$ \\
\hline & -0.923 & -0.938 & -0.937 & -0.916 & -0.955 & -0.916 \\
\hline \multirow[t]{2}{*}{ Institutional Quality } & $-1.349^{* * *}$ & $-1.374^{\star * *}$ & $-1.322^{\star \star \star}$ & $-1.053^{\star \star *}$ & $-1.299^{* * *}$ & $-1.368^{\star \star \star}$ \\
\hline & -0.361 & -0.356 & -0.36 & -0.376 & -0.368 & -0.37 \\
\hline \multirow[t]{2}{*}{ Currency crisis dummy } & & $10.963^{*}$ & $10.963^{*}$ & $13.580^{* *}$ & & \\
\hline & & -6.556 & -6.556 & -6.696 & & \\
\hline \multirow[t]{2}{*}{ Debt crisis dummy } & & & 4.451 & & & \\
\hline & & & -4.131 & & & \\
\hline \multirow[t]{2}{*}{ Latin America dummy } & $26.957^{* \star \star}$ & $26.468^{* * *}$ & $25.810^{* \star *}$ & $20.860^{* \star *}$ & $25.605^{\star \star *}$ & $26.790^{\star * *}$ \\
\hline & -4.748 & -4.786 & -4.765 & -4.468 & -4.74 & -4.805 \\
\hline \multirow[t]{2}{*}{ Asia dummy } & $-27.51^{* * *}$ & $-28.03^{* * *}$ & $-27.697^{* * *}$ & $-26.020^{* * *}$ & $-27.692^{* * *}$ & $-27.705^{\star * *}$ \\
\hline & -4.111 & -4.127 & -4.147 & -4.239 & -4.154 & -4.205 \\
\hline \multirow{2}{*}{$\begin{array}{l}\text { Floating exchange rate } \\
\text { regime }\end{array}$} & & & & & & 0.805 \\
\hline & & & & & & -3.719 \\
\hline \multirow[t]{2}{*}{ Constant } & $12.989^{* \star}$ & $13.346^{\star *}$ & $13.208^{\star *}$ & $20.966^{* \star *}$ & $15.057^{\star \star}$ & $12.855^{\star *}$ \\
\hline & -6.273 & -6.291 & -6.279 & -5.811 & -6.404 & -6.387 \\
\hline Observations & 390 & 390 & 390 & 349 & 379 & 390 \\
\hline LogLik & -1032.2 & -1030.7 & -1031.38 & -928.1 & -1006.3 & -1032.1 \\
\hline Wald Chi2 & 71.02 & 71.13 & 67.93 & 76.77 & 72.95 & 64.55 \\
\hline Pseudo $R^{2}$ & 0.138 & 0.139 & 0.139 & 0.154 & 0.139 & 0.138 \\
\hline
\end{tabular}

Source: Authors' estimations. 


\section{APPENDIX I. DERIVATIONS OF THEORETICAL EXPRESSIONS}

\section{A. The Household's Optimization Problem:}

Consider the household's optimization problem.

The nominal value of household's wealth in period 1 is equal to

$$
A_{1}=\left[\delta^{*}\left(1+r^{*}\right)(1+\hat{s})+\left(1-\delta^{*}\right)(1+i)\right] A_{0}+(1-\tau) Y_{1}+(1-\tau+\mu \tau) \hat{\varepsilon} Y_{1}
$$

Dividing both sides of the expression by $P_{1}$, we get

$$
\frac{A_{1}}{P_{1}}=\left[\delta^{*}\left(1+r^{*}\right)(1+\hat{s})+\left(1-\delta^{*}\right)(1+i)\right] \frac{A_{0}}{P_{0}} \cdot \frac{P_{0}}{P_{1}}+(1-\tau) \frac{Y_{1}}{P_{1}}+(1-\tau+\mu \tau) \hat{\varepsilon} \frac{Y_{1}}{P_{1}}
$$

which can be rewritten as

$$
\frac{A_{1}}{P_{1}}=\left[\frac{\delta^{*}\left(1+r^{*}\right)(1+\hat{s})+\left(1-\delta^{*}\right)(1+i)}{(1+\hat{p})}\right] \frac{A_{0}}{P_{0}}+(1-\tau) \frac{Y_{1}}{P_{1}}+(1-\tau+\mu \tau) \hat{\varepsilon} \frac{Y_{1}}{P_{1}}
$$

Noting that for sufficiently small shocks $\hat{s}$ and $\hat{p}$, the first order linear approximation of the expression in square brackets is

$$
\frac{\delta^{*}\left(1+r^{*}\right)(1+\hat{s})+\left(1-\delta^{*}\right)(1+i)}{(1+\hat{p})} \cong 1+\delta^{*}\left(r^{*}+\hat{s}\right)+\left(1-\delta^{*}\right)(i)-\hat{p}
$$

and letting $a_{1}=\frac{A_{1}}{P_{1}}, a_{0}=\frac{A_{0}}{P_{0}}$ and $y_{1}=\frac{Y_{1}}{P_{1}}$, we get the following expression for the value of household's wealth in period 1 expressed in real terms.

$a_{1} \cong a_{0}\left(\left[1+\delta^{*}\left(r^{*}+\hat{s}\right)+\left(1-\delta^{*}\right)(i)-\hat{p}\right]+(1-\tau) \frac{y_{1}}{a_{0}}+(1-\tau+\mu \tau) \hat{\varepsilon} \frac{y_{1}}{a_{0}}\right)$

Further letting $l_{1}=\frac{1-\tau(1-\mu)}{a_{0} / y_{1}}, k_{1}=\frac{(1-\tau)}{a_{0} / y_{1}}$, we have the following:

$a_{1} \cong a_{0}\left[1+\delta^{*}\left(r^{*}+\hat{s}\right)+\left(1-\delta^{*}\right)(i)-\hat{p}+k_{1}+l_{1} \hat{\varepsilon}\right]$

Noting that, at the optimum, $c_{1}=a_{1}$ we have

$c_{1} \cong a_{0}\left[1+\delta^{*}\left(r^{*}+\hat{s}\right)+\left(1-\delta^{*}\right)(i)-\hat{p}+k_{1}+l_{1} \hat{\varepsilon}\right]$ 
Then, the expected value and the variance of real consumption are given by the following expressions:

$$
\begin{aligned}
& E\left[c_{1}\right] \cong a_{0}+k_{1} a_{0}+a_{0}\left[\delta^{*}\left(r^{*}+E(\hat{s})\right)+\left(1-\delta^{*}\right)(i)+l_{1} E(\hat{\varepsilon})-E(\hat{p})\right] \\
& \operatorname{Var}\left[c_{1}\right] \cong\left(a_{0}\right)^{2}\left[V\left(\delta^{*} \hat{s}+l_{1} \hat{\varepsilon}\right)+V(\hat{p})-2 \operatorname{Cov}\left(\left(\delta^{*} \hat{s}+l_{1} \hat{\varepsilon}\right), \hat{p}\right)\right] \\
& \cong\left(a_{0}\right)^{2}\left[\left(\delta^{*}\right)^{2} V(\hat{s})+\left(l_{1}\right)^{2} V(\hat{\varepsilon})+2 \delta^{*} l_{1} \operatorname{Cov}(\hat{s}, \hat{\varepsilon})-2 \delta^{*} \operatorname{Cov}(\hat{s}, \hat{p})-2 l_{1} \operatorname{Cov}(\hat{\varepsilon}, \hat{p})\right]
\end{aligned}
$$

Plugging the expressions for $E\left[c_{1}\right]$ and $\operatorname{Var}\left[c_{1}\right]$ into the household's utility function $E\left(c_{1}\right)-\frac{\gamma}{2} V\left(c_{1}\right)$ and differentiating it with respect to $\delta^{*}$, we obtain the following f.o.c:

$a_{0}\left(r^{*}-i\right)+a_{0} E_{o}[\hat{s}]-\gamma a_{0}^{2}\left[\left(\delta^{*}\right) V(\hat{s})-\operatorname{Cov}(\hat{s}, \hat{p})+l_{1} \operatorname{Cov}(\hat{s}, \hat{\varepsilon})\right]=0$

which gives us the following expression for the optimal share of household's financial wealth held in foreign currency bonds:

$$
\delta^{*}=\frac{\left(r^{*}+E_{o}[\hat{s}]-i\right)}{\gamma a_{0} V(\hat{s})}+\frac{\operatorname{Cov}(\hat{s}, \hat{p})}{V(\hat{s})}-l_{1} \frac{\operatorname{Cov}(\hat{s}, \hat{\varepsilon})}{V(\hat{s})}
$$

Also, given that $\hat{p}=\alpha \hat{p}_{T}+(1-\alpha) \hat{p}_{N T}$, it can also be re-written as follows:

$$
\delta^{*}=\frac{\left(r^{*}+E_{o}[\hat{s}]-i\right)}{\gamma a_{0} V(\hat{s})}+\left[\alpha\left(\frac{\operatorname{Cov}\left(\hat{s}, \hat{p}_{T}\right)}{V(\hat{s})}\right)+(1-\alpha)\left(\frac{\operatorname{Cov}\left(\hat{s}, \hat{p}_{N T}\right)}{V(\hat{s})}\right)\right]-l_{1}\left(\frac{\operatorname{Cov}(\hat{s}, \hat{\varepsilon})}{V(\hat{s})}\right)
$$

In addition, the term $\frac{\operatorname{Cov}(\hat{s}, \hat{p})}{V(\hat{s})}$ can be re-written as follows:

$$
\frac{\operatorname{Cov}(\hat{s}, \hat{p})}{V(\hat{s})}=\frac{V(\hat{p})+\operatorname{Cov}(\hat{p}, \hat{e})}{V(\hat{p})+V(\hat{e})+2 \operatorname{Cov}(\hat{p}, \hat{e})}
$$

Given that $\operatorname{Cov}(\hat{s}, \hat{p})=\operatorname{Cov}(\hat{e}+\hat{p}, \hat{p})=V(\hat{p})+\operatorname{Cov}(\hat{p}, \hat{e})$ and

$V(\hat{s})=V(\hat{e}+\hat{p})=V(\hat{e})+V(\hat{p})+2 \operatorname{Cov}(\hat{p}, \hat{e})$

$\frac{V(\hat{p})+\operatorname{Cov}(\hat{p}, \hat{e})}{V(\hat{p})+V(\hat{e})+2 \operatorname{Cov}(\hat{p}, \hat{e})}$ is analogous to the MVP term in Ize and Levy-Yeyati (2003). 


\section{B. The Debt Manager's Optimization Problem:}

Consider the government's optimization problem.

Recall that the budget constraint (in nominal terms) is as follows:

$G_{1} \leq \tau(1+\hat{\varepsilon}) Y_{1}-\mu \tau \hat{\varepsilon} Y_{1}-\left(\delta^{\prime}\left(1+r^{*}\right)(1+\hat{s})+\left(1-\delta^{\prime}\right)(1+i)\right) D_{0}$

Dividing both sides by $P_{1}$, we get

$\frac{G_{1}}{P_{1}} \leq \tau(1+\hat{\varepsilon}) \frac{Y_{1}}{P_{1}}-\mu \tau \hat{\varepsilon} \frac{Y_{1}}{P_{1}}-\left[\delta^{\prime}\left(1+r^{*}\right)(1+\hat{s})+\left(1-\delta^{\prime}\right)(1+i)\right] \frac{D_{0}}{P_{0}} \cdot \frac{P_{0}}{P_{1}}$

which can be re-written as

$\frac{G_{1}}{P_{1}} \leq \tau(1+\hat{\varepsilon}) \frac{Y_{1}}{P_{1}}-\mu \tau \hat{\varepsilon} \frac{Y_{1}}{P_{1}}-\left[\frac{\delta^{\prime}\left(1+r^{*}\right)(1+\hat{s})+\left(1-\delta^{\prime}\right)(1+i)}{(1+\hat{p})}\right] \frac{D_{0}}{P_{0}}$

Noting that for sufficiently small shocks $\hat{s}$ and $\hat{p}$, the first order linear approximation of the expression in square brackets is

$\frac{\delta^{*}\left(1+r^{*}\right)(1+\hat{s})+\left(1-\delta^{*}\right)(1+i)}{(1+\hat{p})} \cong 1+\delta^{*}\left(r^{*}+\hat{s}\right)+\left(1-\delta^{*}\right)(i)-\hat{p}$

and letting $g_{1}=\frac{G_{1}}{P_{1}}, d_{0}=\frac{D_{0}}{P_{0}}$ and $y_{1}=\frac{Y_{1}}{P_{1}}$, the budget constraint (expressed in real terms) can be re-written as

$g_{1} \cong d_{0}\left[k_{1}+f_{1} \hat{\varepsilon}-\left(1+\delta^{\prime}\left(r^{*}+\hat{s}\right)+\left(1-\delta^{\prime}\right)(i)-\hat{p}\right)\right]$

where $k_{1}=\frac{\tau}{d_{0} / y_{1}}$ and $f_{1}=\frac{\tau(1-\mu)}{d_{0} / y_{1}}$

Then, the expected value and the variance of fiscal buffer $g_{1}$ are given by the following expressions:

$E\left[g_{1}\right] \cong k_{1} d_{0}-d_{0}+d_{0}\left[-\delta^{\prime}\left(r^{*}+E(\hat{s})\right)-\left(1-\delta^{\prime}\right)(i)+f_{1} E(\hat{\varepsilon})+E(\hat{p})\right]$ 


$$
\begin{aligned}
\operatorname{Var}\left[g_{1}\right] & \cong\left(d_{0}\right)^{2}\left[V\left(f_{1} \hat{\varepsilon}-\delta^{\prime} \hat{s}\right)+V(\hat{p})+2 \operatorname{Cov}\left(\left(f_{1} \hat{\varepsilon}-\delta^{\prime} \hat{s}\right), \hat{p}\right)\right] \\
& \cong\left(d_{0}\right)^{2}\left[\left(\delta^{\prime}\right)^{2} V(\hat{s})+\left(f_{1}\right)^{2} V(\hat{\varepsilon})-2 \delta^{\prime} f_{1} \operatorname{Cov}(\hat{s}, \hat{\varepsilon})-2 \delta^{\prime} \operatorname{Cov}(\hat{s}, \hat{p})+2 f_{1} \operatorname{Cov}(\hat{\varepsilon}, \hat{p})\right]
\end{aligned}
$$

Plugging the expressions for $E\left[g_{1}\right]$ and $\operatorname{Var}\left[g_{1}\right]$ into the debt manager's objective function and differentiating with respect to $\delta^{\prime}$, we obtain the following f.o.c.:

$$
-d_{0}\left(r^{*}+E(\hat{s})-i\right)-\gamma\left(d_{0}\right)^{2}\left[\delta^{\prime} V(\hat{s})-f_{1} \operatorname{Cov}(\hat{s}, \hat{\varepsilon})-\operatorname{Cov}(\hat{s}, \hat{p})\right]=0
$$

which gives us the optimal share of dollar debt:

$$
\delta^{\prime}=-\frac{\left(r^{*}+E(\hat{s})-i\right)}{\gamma d_{0} V(\hat{s})}+\frac{\operatorname{Cov}(\hat{s}, \hat{p})}{V(\hat{s})}+f_{1}\left(\frac{\operatorname{Cov}(\hat{s}, \hat{\varepsilon})}{V(\hat{s})}\right)
$$

\section{Domestic Bond Market Clearing Condition:}

The households' demand for domestic dollar debt is

$$
\delta^{*} a_{0}=\frac{\left(r^{*}+E(\hat{s})-i\right)}{\gamma V(\hat{s})}+\left[\alpha\left(\hat{\beta}_{T}\right)+(1-\alpha)\left(\hat{\beta}_{N T}\right)\right] a_{0}-l_{1}\left(\hat{\beta}_{\varepsilon}\right) a_{0}
$$

The government's supply of domestic dollar debt is

$$
\delta^{\prime} d_{0}=-\frac{\left(r^{*}+E(\hat{s})-i\right)}{\gamma V(\hat{s})}+\left[\alpha\left(\hat{\beta}_{T}\right)+(1-\alpha)\left(\hat{\beta}_{N T}\right)\right] d_{0}+f_{1}\left(\hat{\beta}_{\varepsilon}\right) d_{0}
$$

Since in equilibrium, $\delta^{*} A_{0}=\delta^{\prime} D_{0}$, and because $A_{0}=D_{0}$, the market clearing interest rate is implicitly given by the following equation: $\frac{\left(r^{*}+E[\hat{s}]-i\right)}{\gamma a_{0} V(\hat{s})}=\frac{\left(\hat{\beta}_{\varepsilon}\right)\left(l_{1}+f_{1}\right)}{2}$

Then, setting $\delta^{*}=\delta^{\prime}=\delta^{* *}$, equilibrium share of foreign currency debt is

$$
\begin{aligned}
& \delta^{* *}=\left[\alpha\left(\hat{\beta}_{T}\right)+(1-\alpha)\left(\hat{\beta}_{N T}\right)\right]+\frac{\left(f_{1}-l_{1}\right)}{2}\left(\hat{\beta}_{\varepsilon}\right), \text { which can be re-written as follows: } \\
& \delta^{* *}=\left[\alpha\left(\hat{\beta}_{T}\right)+(1-\alpha)\left(\hat{\beta}_{N T}\right)\right]+\left(\frac{2 \tau(1-\mu)-1}{2}\right)\left(\frac{\hat{\beta}_{\varepsilon}}{d_{0} / y_{1}}\right)
\end{aligned}
$$




\section{APPENDIX II. DERIVATIONS OF CORRECTED INTERACTION EFFECT}

The magnitude of the interaction effect in Tobit models does not equal the marginal effect of the interaction term, and its value and statistical significance is not calculated by standard software or derived in the literature. This section presents the correct way to estimate the magnitude of the interaction effect in nonlinear Tobit models, and the expressions for the marginal effects of the variables involved in the interaction term.

Consider the Tobit panel data model:

$y_{i t}=\max \left(0, \mathbf{x}_{i t} \boldsymbol{\beta}+u_{i t}\right), \quad t=1,2, \ldots, T$

$u_{i t} \mid \mathbf{x}_{i t} \approx \operatorname{Normal}\left(0, \sigma^{2}\right)$

To simplify the derivations below, I re-expresses the index $\mathbf{x} \boldsymbol{\beta}$ in terms of the relevant interacting variables $\left(x_{1}\right.$, procyclicality of fiscal policy, and $x_{2}$, countercyclicality of the exchange rate, and their associated coefficients $\beta_{1}$ and $\beta_{2}$ ) and the rest of the controls captured in matrix $X$ and vector of coefficients B :

$y^{*}=\mathbf{x} \boldsymbol{\beta}+u=\beta_{1} x_{1}+\beta_{2} x_{2}+\beta_{12} x_{1} x_{2}+X \mathrm{~B}+u$

To find an explicit expression for $E(y \mid \mathbf{x})$, note that:

$$
\begin{aligned}
E(y \mid \mathbf{x}) & =P(y=0 \mid \mathbf{x}) \cdot 0+P(y>0 \mid \mathbf{x}) . E(y \mid \mathbf{x}, y>0) \\
& =P(y>0 \mid \mathbf{x}) E(y \mid \mathbf{x}, y>0)
\end{aligned}
$$

Using the expressions derived in Wooldridge (2005):

$$
\begin{aligned}
E(y \mid \mathbf{x}) & =P(y=0 \mid \mathbf{x}) \cdot 0+P(y>0 \mid \mathbf{x}) \cdot E(y \mid \mathbf{x}, y>0) \\
& =\Phi\left(\frac{\mathbf{x} \boldsymbol{\beta}}{\sigma}\right)\left\{\mathbf{x} \boldsymbol{\beta}+\sigma\left[\frac{\phi\left(\frac{\mathbf{x} \boldsymbol{\beta}}{\sigma}\right)}{\Phi\left(\frac{\mathbf{x} \boldsymbol{\beta}}{\sigma}\right)}\right]\right\}=\Phi\left(\frac{\mathbf{x} \boldsymbol{\beta}}{\sigma}\right) \mathbf{x} \boldsymbol{\beta}+\sigma \phi\left(\frac{\mathbf{x} \boldsymbol{\beta}}{\sigma}\right)
\end{aligned}
$$

\section{A. Marginal Effects of Variables in Levels and Interaction Term on $E(y \mid \mathbf{x})$}

- $\quad$ The marginal effect on the conditional expectation of debt dollarization of a $1 \%$ change in the procyclicality of fiscal policy $\left(\gamma_{1}\right)$, is computed as: 


$$
\begin{aligned}
& \gamma_{1}=\frac{\partial E(y \mid \mathbf{x})}{\partial x_{1}}=\frac{\partial P(y>0 \mid \mathbf{x})}{\partial x_{1}} \cdot E(y \mid \mathbf{x}, y>0)+P(y>0 \mid \mathbf{x}) \frac{\partial E(y \mid \mathbf{x}, y>0)}{\partial x_{1}} \\
& =\left(\frac{\beta_{1}+\beta_{12} x_{2}}{\sigma}\right) \phi\left(\frac{\mathbf{x} \boldsymbol{\beta}}{\sigma}\right)\left\{\mathbf{x} \boldsymbol{\beta}+\sigma\left[\frac{\phi\left(\frac{\mathbf{x} \boldsymbol{\beta}}{\sigma}\right)}{\Phi\left(\frac{\mathbf{x} \boldsymbol{\beta}}{\sigma}\right)}\right]\right\}+\Phi\left(\frac{\mathbf{x} \boldsymbol{\beta}}{\sigma}\right)\left(\beta_{1}+\beta_{12} x_{2}\right)\left\{1-\left(\frac{\mathbf{x} \boldsymbol{\beta}}{\sigma}\right) \frac{\phi\left(\frac{\mathbf{x} \boldsymbol{\beta}}{\sigma}\right)}{\Phi\left(\frac{\mathbf{x} \boldsymbol{\beta}}{\sigma}\right)}-\frac{\phi\left(\frac{\mathbf{x} \boldsymbol{\beta}}{\sigma}\right)^{2}}{\Phi\left(\frac{\mathbf{x} \boldsymbol{\beta}}{\sigma}\right)^{2}}\right\} \\
& =\left(\beta_{1}+\beta_{12} x_{2}\right) \phi\left(\frac{\mathbf{x} \boldsymbol{\beta}}{\sigma}\right)\left(\frac{\mathbf{x} \boldsymbol{\beta}}{\sigma}\right)+\left(\beta_{1}+\beta_{12} x_{2}\right)\left[\frac{\phi\left(\frac{\mathbf{x} \boldsymbol{\beta}}{\sigma}\right)^{2}}{\Phi\left(\frac{\mathbf{x} \boldsymbol{\beta}}{\sigma}\right)}\right]+\Phi\left(\frac{\mathbf{x} \boldsymbol{\beta}}{\sigma}\right)\left(\beta_{1}+\beta_{12} x_{2}\right)- \\
& \left(\beta_{1}+\beta_{12} x_{2}\right)\left(\frac{\mathbf{x} \boldsymbol{\beta}}{\sigma}\right) \phi\left(\frac{\mathbf{x} \boldsymbol{\beta}}{\sigma}\right)-\left(\beta_{1}+\beta_{12} x_{2}\right)\left[\frac{\phi\left(\frac{\mathbf{x} \boldsymbol{\beta}}{\sigma}\right)^{2}}{\Phi\left(\frac{\mathbf{x} \boldsymbol{\beta}}{\sigma}\right)}\right]
\end{aligned}
$$

After some cancellations:

$$
\gamma_{1}=\frac{\partial E(y \mid \mathbf{x})}{\partial x_{1}}=\Phi\left(\frac{\mathbf{x} \boldsymbol{\beta}}{\sigma}\right)\left(\beta_{1}+\beta_{12} x_{2}\right)
$$

- Using the same logic, the marginal effect of the countercyclicality of the exchange rate is given by:

$$
\gamma_{2}=\frac{\partial E(y \mid \mathbf{x})}{\partial x_{2}}=\Phi\left(\frac{\mathbf{x} \boldsymbol{\beta}}{\sigma}\right)\left(\beta_{2}+\beta_{12} x_{1}\right)
$$

- The marginal effect of the interaction term, is given by:

$$
\gamma_{3}=\frac{\Delta\left[\frac{\partial E(y \mid \mathbf{x})}{\partial x_{1}}\right]}{\partial x_{2}}=\phi\left(\frac{\mathbf{x} \boldsymbol{\beta}}{\sigma}\right)\left(\beta_{2}+\beta_{12} x_{1}\right)\left(\beta_{1}+\beta_{12} x_{2}\right)+\Phi\left(\frac{\mathbf{x} \boldsymbol{\beta}}{\sigma}\right)\left(\beta_{12}\right)
$$

